
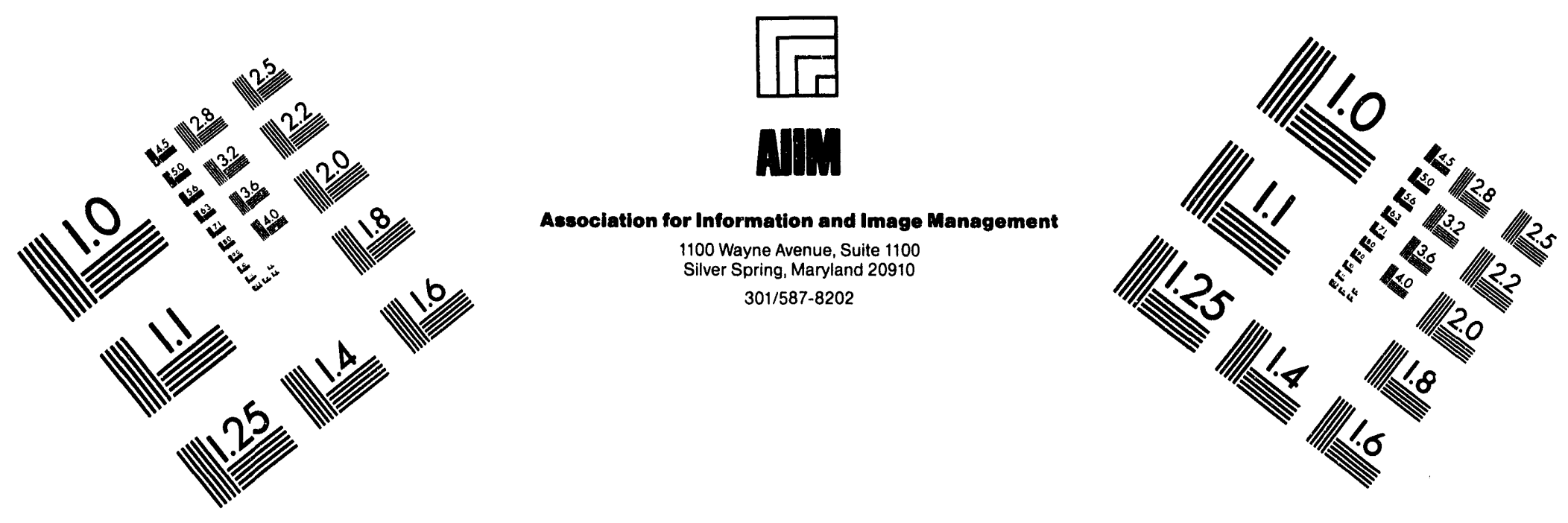

\title{
Centimeter
}

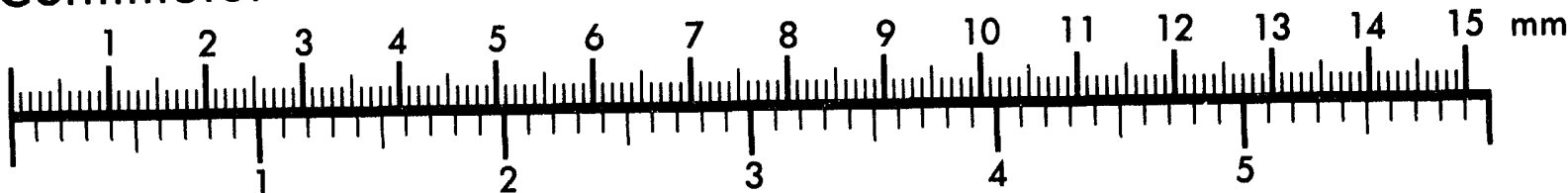

Inches
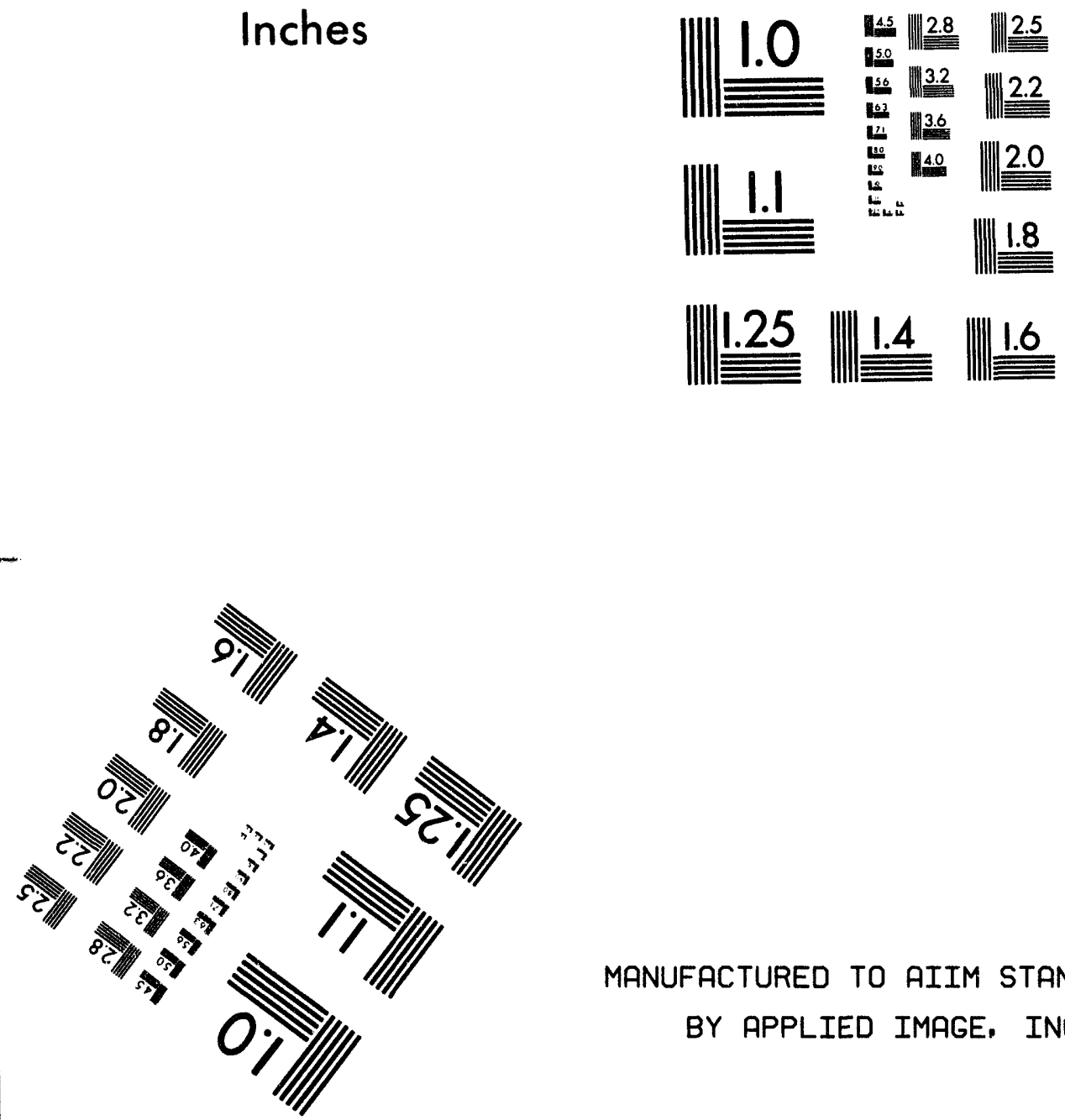

MANUFACTURED TO AIIM STANDARDS

BY APPLIED IMAGE, INC.

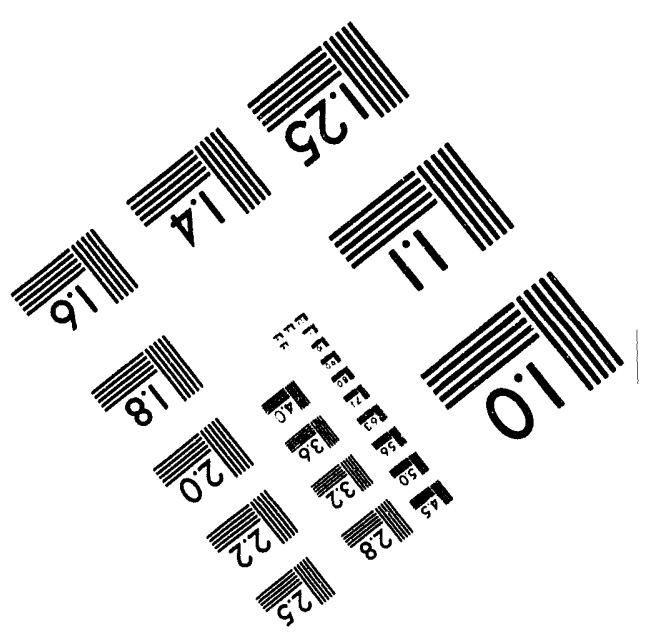



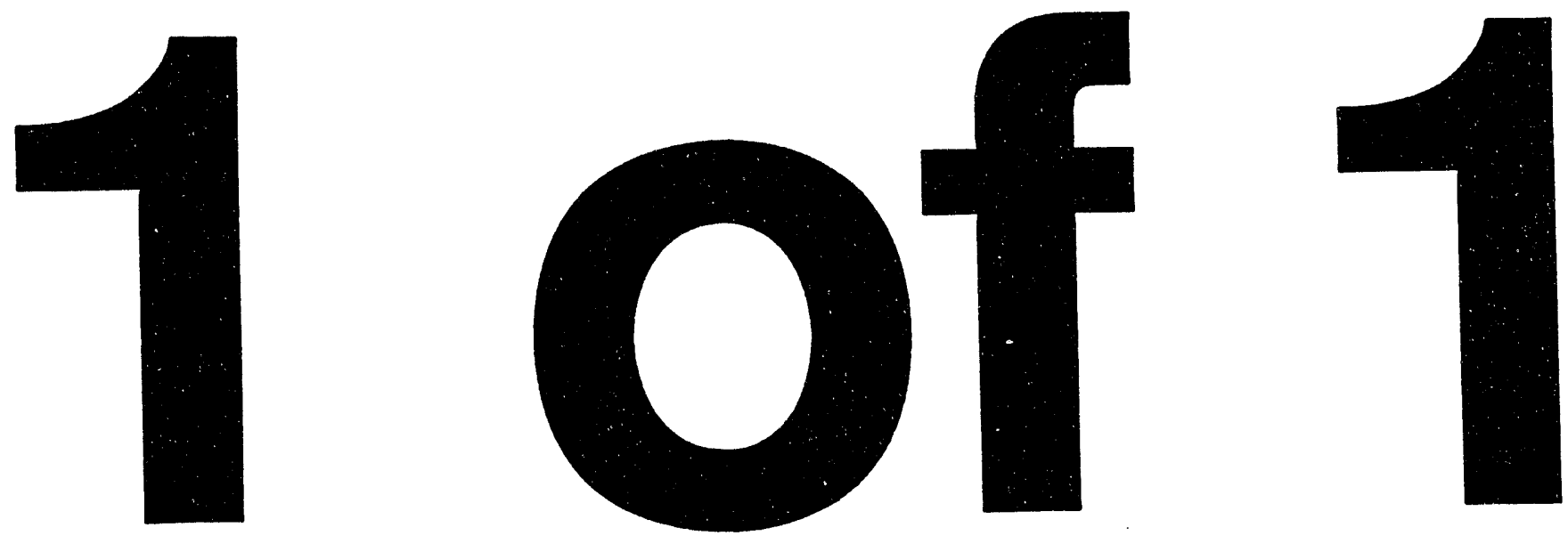


\section{USE OF SAVANNAH RIVER SITE FACILITIES FOR BLEND DOWN OF HIGHLY ENRICHED URANIUM (U)}

\section{AUTHORS:}

W. E. BICKFORD

J. M. MCKIBBEN

FEBRUARY, 1994

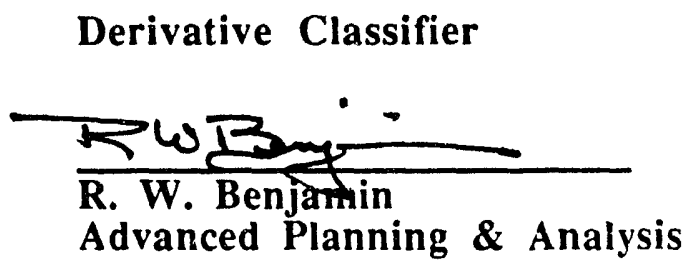

Westinghouse Savannah River Company Savannah River Site Aiken, SC $\mathbf{2 9 8 0 8}$ 
WSRC-RP-93-1262

\section{DISCLAIMER}

This report was prepared as an account of work sponsored by an agency of the United States Government. Neither the United States Government nor any agency thereof, nor any of their employees, makes any warranty, express or implied, or assumes any legal liability of responsibility for the accuracy, completeness, or usefulness of any information, apparatus, product, or process disclosed, or represents that its use would not infringe privately owned rights. Reference herein to any specific commercial product, process, or service by the trade name, trademark, manufacturer, or otherwise, does not necessarily constitute or imply its endorsement, recommendation, or favoring by the United States Government or any agency thereof. The views and opinions of authors expressed herein do not necessarily state or reflect those of the United States Government or any agency thereof. 
USE OF SAVANNAH RIVER SITE FACILITIES

FOR BLEND DOWN OF

HIGHLY ENRICHED URANIUM (U)

PREPARED WITH INPUT FROM THE HEU BLEND DOWN TASK TEAM:

J. M. McKIBBEN, CHAIRMAN

W. E. BICKFORD

C. E. PICKETT

D. F. CHOSTNER

J. S. BULLINGTON

R. L. FRONTROTH

W. G. SMITH

D. L. MCWHORTER

F. E. McKAY

C. E. OLSON

S. A. YANO

APPROVED BY:

T. H. GOULD, MANAGER

STRATEGIC PLANNING \& ANALYSIS

WESTINGHOUSE SAVANNAH RIVER COMPANY

FEBRUARY， 1994

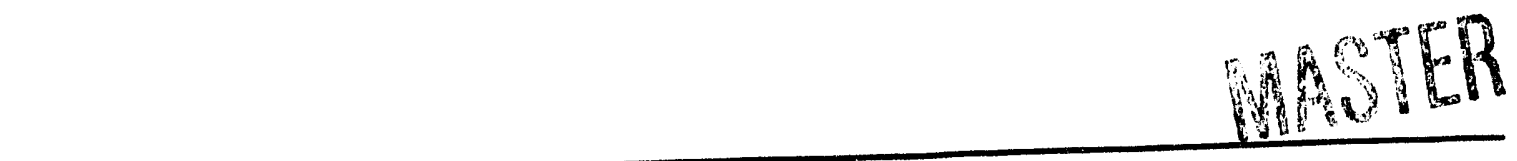

Westinghouse Savannah River Company

Savannah River Site

Aiken, SC 29808

PREPARED FOR THE U. S. DEPARTMENT OF ENERGY UNDER CONTRACT DE-AC09-89SR 18035 


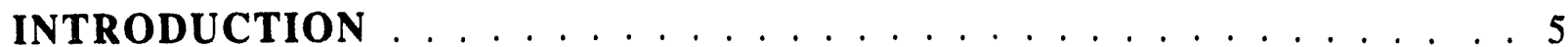

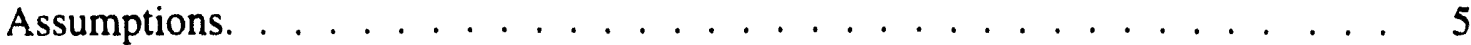

Economics. . . . . . . . . . . . . . . . . . 6

Competing US Commercial Capabilities. . . . . . . . . . . . . . . 7

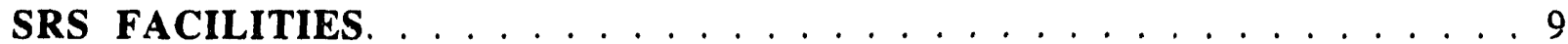

$247-$ F Facility . . . . . . . . . . . . . . . . . . . . . .

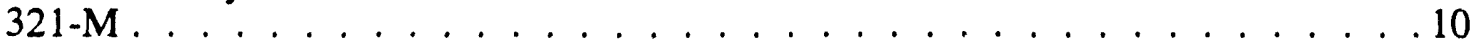

F-and H-Canyons $(221-\mathrm{F}, 221-\mathrm{H}) \ldots \ldots \ldots \ldots \ldots$

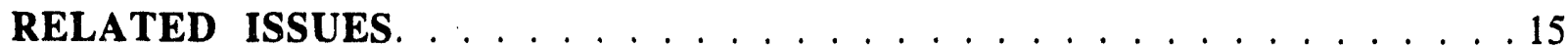

Uranium Isotopic Impurities $\ldots \ldots \ldots \ldots$

DU Feed Stock and Commercial Fuel Specifications . . . . . . . . . . . 16

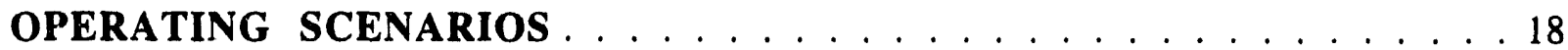

More Feasible Options for Blend Down of 500 MT HEU at SRS Facilities:

1. 321-M Making LE Metal . . . . . . . . . . . . . . . . . . . . . . . 18

2. 221-F Canyon FA Line Making $\mathrm{LE} \mathrm{UO}_{3}$ Powder. . . . . . . . . . . . . . 20

3. 221-F or H Making L.E Uranyl Nitrate Solution for Shipment Offsite. . . . . . . . . . 21 .

4. 221-H LE Uranyl Nitrate Shipped to A-Line Making LE UO ${ }_{3}$ Powder. . . . . . . . . . 24

Less Feasible Options for Blend Down of 500 MT HEU at SRS Facilities:

5. 221-H, Uranium Solidification Facility (USF) Making $\mathrm{UO}_{3}$ Powder . . . . . . . . . . 25

6. $221-\mathrm{H}$, USF, Making $\mathrm{HE} \mathrm{UO}_{3}$, Blending to $\mathrm{LE} \mathrm{UO}_{3}$ in $247-\mathrm{F} \ldots \ldots \ldots \ldots$

7. 321-M Making LEU Metal, 221-F, A-Line Converting to $\mathrm{UO}_{3}$ Powder . . . . . . . 30

8. 321-M Making LEU Metal, 221-H, USF Converting to $\mathrm{UO}_{3}$ Powder . . . . . . . . 32

COMPARATIVE ASSESSMENT OF MOST LIKELY OPTIONS . . . . . . . . 34

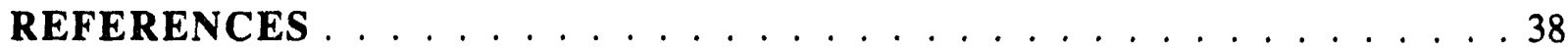

APPENDIX A - Uranium Mass Balances and Market Value . . . . . . . A.1

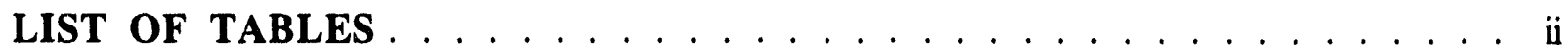

Table S.1 Summary of Competitive Options for HEU Blend Down

of 500 MT of HEU at SRS Facilities. . . . . . . . . . . . . . . . . 4

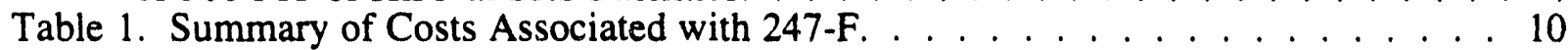

Table 2. Summary of Costs Associated with $321-\mathrm{M} \ldots \ldots \ldots \ldots \ldots$

Table 3. Capital Equipment for F-Canyon . . . . . . . . . . . . . . . . . . . . . 13

Table 4. Safety and Environmental Studies for F-Canyon . . . . . . . . . . . . . . 14

Table 5. Summary of Costs Associated with 221-F. . . . . . . . . . . . . 14

Table 6. Typical HE Uranium Isotopic Content. . . . . . . . . . . . . . . . . . 15

Table 7. ASTM Specification for Uranium Isotopic Impurities . . . . . . . . . . . . 15

Table 8. Summary of Costs Associated with Option 1. . . . . . . . . . . . . . 19

Table 9. Present Worth for Option $1, \mathrm{n}=20$ yrs. . . . . . . . . . . . . . . . . . 19

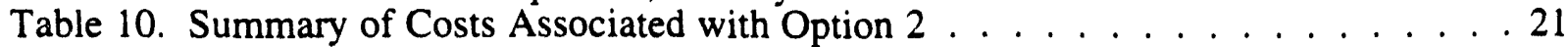

Table 11. Present Worth for Option $2, \mathrm{n}=20$ yrs. . . . . . . . . . . . . 21

Table 12. Summary of Costs Associated with Option $3 \ldots \ldots \ldots \ldots \ldots \ldots \ldots$ 
Table 13. Present Worth for Option 3, $n=20$ yrs. . . . . . . . . . . . . . . 23

Table 14. Summary of Costs Associated with 221-F, Uranyl Nitrate Product . . . . . . . 23

Table 15. Summary of Costs Associated with Option 4 . . . . . . . . . . . . . . . 24

Table 16. Present Worth for Option 4, $n=20$ yrs. . . . . . . . . . . . . . . . . 25

Table 17. Summary of Costs for 221-H, USF LEU UO3 Power Product . . . . . . . . . . 26

Table 18. Summary of Costs Associated with Option 5 . . . . . . . . . . . . . . 27

Table 19. Present Worth for Option $5, \mathrm{n}=20$ yrs. . . . . . . . . . . . . . . 27

Table 20. Summary of Costs Associated with Option 6 . . . . . . . . . . . . . 29

Table 21. Present Worth for Option $6, n=20$ yrs. . . . . . . . . . . . . . . . . . . . 29

Table 22. Summary of Costs Associated with Option $7 \ldots \ldots$. . . . . . . . . 31

Table 23. Present Worth for Option $7, n=20$ yrs. . . . . . . . . . . . . . . . . 31

Table 24. Summary of Costs Associated with Option $8 \ldots \ldots . \ldots 33$

Table 25. Present Worth for Option 8, $n=20$ yrs. . . . . . . . . . . . . . . 33

Table 26 Quantitative Attributes for SRS Options Examined . . . . . . . . . . . . . 35

Table 27. Facility Use for HEU Blend Down Processing Options at SRS . . . . . . . . . 37

Table A.1 Summary of Material Balances and Estimated Value of Blended HEU . . . . . . . . . . . . . . . . . . . . A.1

Table A.2 Kg of Product Per Kg HEU Input . . . . . . . . . . . . . . . . . . . . . A.2

Table A.3 SWU Equivalent for HEU Blend Down . . . . . . . . . . . . . . . . . . . A.3

Table A.4 Representative Spot Market Prices for Nuclear Material . . . . . . . . . . . A.4

Table A.5 Product Value for Commercial Fuel Feed Stock . . . . . . . . . . . . . . . A.5

LIST OF FIGURES $\ldots \ldots \ldots \ldots \ldots \ldots \ldots \ldots \ldots \ldots \ldots$ iii

Figure S.1 Options for Blending Down Highly Enriched Metal at SRS. . . . . . . . . . . 3

Figure A.1 Profit of Blending HEU With Natural Versus Depleted Uranium, as a Function of DU Storage Costs. . . . . . . . . . . . . . . A.7 
Use of Savannah River Site Facilities for Blend-Down of Highly Enriched Uranium 


\section{Summary}

The Department of Energy Savannah River Operations Office (DOE-SR) requested that Westinghouse Savannah River Company (WSRC) assess the use of existing Savannah River Site (SRS) facilities for the conversion of highly enriched uranium (HEU) to low enriched uranium (LEU). Blending HEU with existing supplies of depleted uranium (DU) would produce material with less than 5\% U-235 content for use in commercial nuclear reactors. The request indicated that as much as 500 to $1000 \mathrm{MT}$ of HEU would be available for conversion over a 20 -year period.

Existing facilities at the Savannah River Site are capable of producing LEU in the form of uranium trioxide $\left(\mathrm{UO}_{3}\right)$ powder, uranyl nitrate $\left[\mathrm{UO}_{2}\left(\mathrm{NO}_{3}\right)_{2}\right]$ solution, or metal. Additional processing, and additional facilites, would be required to convert the LEU to uranium dioxide $\left(\mathrm{UO}_{2}\right)$ or uranium hexafluoride $\left(\mathrm{UF}_{6}\right)$, the normal inputs for commercial fuel fabrication. This study's scope does not include the cost for new conversion facilities. However, the low estimated cost per kilogram of blending HEU to LEU in SRS facilities indicates that even with fees for any additional conversion to $\mathrm{UO}_{2}$ or $\mathrm{UF}_{6}$, blend-down would still provide a product at significantly below the spot market price for LEU from traditional enrichment services.

The body of the report develops a number of possible facility/process combinations for SRS. The most likely options, summarized in Table S.1 below, are as follows:

- 321-M produces a metal product

- 221-F produces uranyl nitrate solution, converted to $\mathrm{UO}_{3}$ powder in FA Line

- $\quad 221-\mathrm{F}$ or $221-\mathrm{H}$ canyon produces a uranyl nitrate solution product

- 221-H produces a uranyl nitrate solution, shipped to FA Line to make $\mathrm{UO}_{3}$ powder

These options are shown in summary figure S.1.

The Uranium Solidification Facility (USF), if completed, could also process uranyl nitrate solution from $221-\mathrm{H}$ to $\mathrm{UO}_{3}$ powder. However, USF throughput capacities would limit its use to smaller blend-down campaigns.

The primary conclusion of this study is that SRS has facilities available that are capable of satisfying the goals of a national program to ble. 'd HEU to below $5 \%$ U-235. This preliminary assessment concludes tha several facility/process options appear cost-effective. Finally, SRS is a secu.e DOE site with all requisite security and safeguards programs, personnel skills, nuclear criticality safety controls, accountability programs, and supperting infrastructure to handle large quantities of special nuclear materials ( $S \wedge M$ ), with over 40 years of experience in safe SNM production. 
Figure S.1 Options for Blending Down

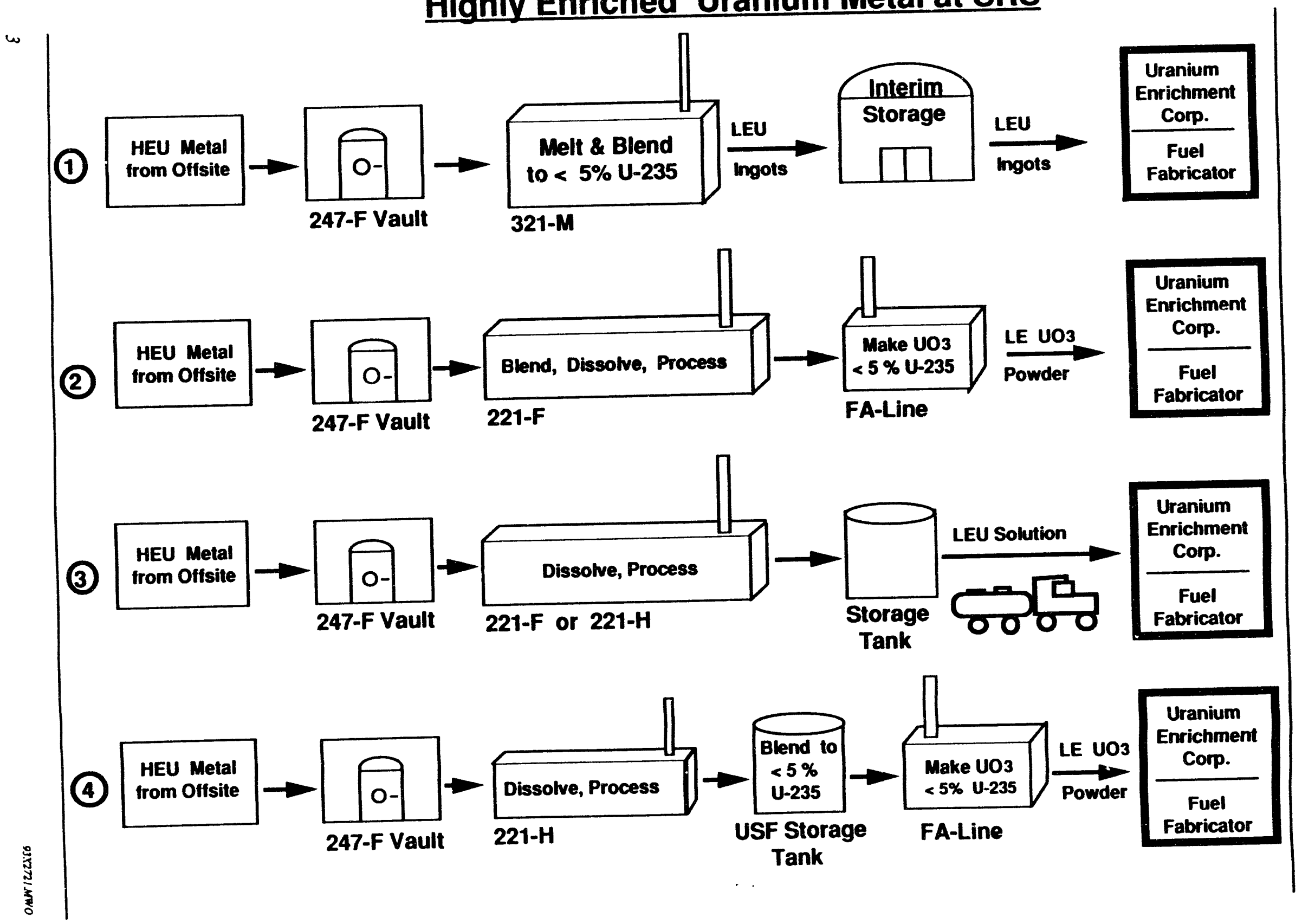


Table S.1 Summary of Competi:.ve Options for Blend Down of 500 MT of HEU at SRS Facilities

\begin{tabular}{|c|c|c|c|c|c|c|}
\hline $\begin{array}{l}\text { Facility/ } \\
\text { process } \\
\text { option }\end{array}$ & $\begin{array}{l}\text { A. } \\
\begin{array}{l}\text { peU } \\
\text { form }\end{array}\end{array}$ & $\begin{array}{ll}\text { Initial } & \text { C. } \\
\text { costs } & \\
\text { ( } \$ \text { million) }\end{array}$ & $\begin{array}{l}\text { Operating D. } \\
\text { costs } \\
(\$ \text { million/yr) }\end{array}$ & $\begin{array}{l}\text { Current } \\
\text { worth } \\
\text { ( } \$ \text { million) }\end{array}$ & $\begin{array}{l}\text { Efrective } \\
\text { price } \\
\text { (SMkg HEU) }\end{array}$ & $\begin{array}{l}\text { Year } \\
\text { available }\end{array}$ \\
\hline 1. $321-\mathrm{M}$ & Metal & 28.2 & 32.5 & 373 & 745 & FY 95 \\
\hline $\begin{array}{l}\text { 2. 221-F, } \\
\text { FA Line }\end{array}$ & $\mathrm{UO}_{3}$ & 39.0 & 69.0 & 770 & 1,540 & FY 99 \\
\hline $\begin{array}{l}\text { 3. } 221-\mathrm{F} \text { or } \\
221-\mathrm{H}\end{array}$ & $\begin{array}{l}\text { Uranyl } \\
\text { nitrate } \\
\text { solution }\end{array}$ & 33.0 & 62.0 & 690 & 1,380 & FY 97,02 \\
\hline $\begin{array}{l}\text { 4. } 221-\mathrm{H}, \\
\text { solution } \\
\text { to FA Line }\end{array}$ & $\mathrm{UO}_{3}$ & 45.0 & 69.0 & 776 & 1,552 & FY 02 \\
\hline
\end{tabular}

Description:

1. The HEU metal is melted in 321-M vacuum furnaces and blended with DU metal. This is relatively easy to implement. However, purified DU metal supplies are insufficient to convert the entire $500 \mathrm{MT}$ HEU inventory. The metal product is judged least desirable for input into a commercial fuel fabrication process. The 321-M facility is also unfavorably located near the site perimeter and its administrative area.

2. The HEU metal is dissolved in F Canyon, and blended with DU feedstock (metal or $\mathrm{UO}_{3}$ powder), producing LE uranyl nitrate solution. This solution is passed through the second uranium extraction cycle, and sent to $\mathrm{FA}$ Line for denitrating to a low enriched $\mathrm{UO}_{3}$ powder. Canyon operating costs are high relative to $321-\mathrm{M}$; however, the final product is judged more acceptable for input to a commercial fuel fabrication process. SRS also has sufficient quantity of high-purity depleted $\mathrm{UO}_{3}$ powder on hand to convert the entire $500 \mathrm{MT}$ of HEU.

3. The HEU metal is dissolved in $221-\mathrm{F}$ and blended with DU feedstock (metal or $\mathrm{UO}_{3}$ powder), producing LE uranyl nitrate solution, which is passed through the second uranium extraction cycle. In $221-\mathrm{H}$, the metal is dissolved and the HE uranyl nitrate solution is passed through the second uranium extraction cycle. Blending with depleted uranyl nitrate solution occurs outside 221-H in the USF storage tank. In both cases the product is in the form of LE uranyl nitrate solution, which would be loaded into licensed tank trucks and shipped offsite to a commercial fuel fabrication facility. This is estimated to be slightly cheaper than full operation of F Canyon and FA Line. Shipment of uranyl nitrate solution would require DOE approval.

4. H Canyon is used for dissolution of HEU metal to HE uranyl nitrate solution. Blending with depleted uranyl nitrate solution occurs outside $221-\mathrm{H}$ in the USF storage tank. The solution is sent to FA Line for conversion to $\mathrm{UO}_{3}$ powder. This requires $\mathrm{DOE}$ approval for shipment of $\mathrm{LE}$ uranyl nitrate solutions.

Table Columns:

A. Final form of the LEU product from SRS.

B. Estimated one-time capital equipment, facility and safety/environmental stuciy costs.

C. Annual operating costs include a baseline for surveillance and mainten.nce (S\&M) under the environmental restoration (ER) program.

D. Present worth of option, based on capital and annual operating expenses over a 20-year period, with annual interest at $7 \%$. (Results for interest rates from $5 \%$ to $10 \%$ are given in the report).

E. Net cost of processing on a per $\mathrm{kg}$ HEU basis $=($ column E $) /\left(5 \times 10^{5} \mathrm{~kg}\right)$. Options summarized here are all significantly below the target of $\$ 15,000 / \mathrm{kg}$. This can be converted to a $\$ / \mathrm{kg}$ product basis, assuming $-20 \mathrm{~kg}$ product per $\mathrm{kg} \mathrm{HEU}$ when blending to $5 \% \mathrm{U}-235$, and $\sim 30 \mathrm{~kg}$ product per $\mathrm{kg}$ HEU when blending to $3.5 \%$ U-235. 


\section{Introduction}

On December 1, 1992, Westinghouse Savannah River Company (WSRC) was requested by Department of Energy Savannah River Operations Office (DOE-SR) to assess the use of existing Savannah River Site (SRS) facilities for the conversion of highly enriched uranium (HEU) to low enriched uranium (LEU), using depleted uranium (DU) (Ref. 1). The assumed purpose was to eliminate the weapons potential for such material and to make it available for use in commercial nuclear reactor fuels. An initial quick-study response was provided by Westinghouse Savannah River Company (WSRC) on December 4, 1992 (Ref. 2). The purpose of this follow-on study is to address subsequent events and suggestions and incorporate more detail on likely options at SRS.

The assumed original impetus of this study was the potential need to blend down HEU being returned from the nuclear weapons program of both the US and former Soviet Union. Initial draft terms between Russia's Ministry of Atomic Energy (Minatom) and the US Department of State included the following (Ref. 3):

- conversion of HEU ( $\angle 90 \%$ U-235) to low enriched uranium (LEU, less than 20\% U-235).

- conversion rate of no less than 10 metric tons per year (MT/yr) having an average assay of greater than $90 \%$ U-235 in each of the first 5 years, and no less than $30 \mathrm{MT} / \mathrm{yr}$ thereafter. The total purchase is put at approximately $500 \mathrm{MT}$ HEU.

Subsequent negotiations indicated that Russia would complete the blenddown to commercial light water reactor (LWR) enrichment specifications of $4.4 \%$ U-235 using $1.5 \%$ U-235 blend stock, with shipment in the form of UF6 (Ref. 4).

However, it is assumed a quid pro quo reduction of US weapons material could be expected by the Russians. The potential conversion of HEU from dismantled weapons in US stockpile thus still remains a viable option.

\section{Assumptions}

Baseline assumptions were agreed upon during informal discussions with DOE-SR. The most important of these assumptions are listed below.

- All HEU feedstock will be metal.

- Existing SRS stores of depleted $\mathrm{UO}_{3}$ or metal may be used to blend down the HEU.

- The product will be less than 5\% U-235. No minimum was specified. However, the study assumed $5 \%$.

- The final form and purity of the product has not been specified. However, $\mathrm{UO}_{2}$ and $\mathrm{UF}_{6}$ products meeting industry specifications for commercial fuel are assumed to be preferred. Any deviation from these forms may have additional associated cost penalties which should be addressed. 
Since the original study, the following assumptions have been added:

- This study will not consider the blend-down of Russian HEU.

- Blend-down of US HEU remains a viable option.

- The draft Russian purchase is put at $500 \mathrm{MT}$ HEU equivalent, at a rate of $10 \mathrm{MT}$ HEU $(\Sigma 90 \% \mathrm{U}-235)$ per year for 5 years, and $30 \mathrm{MT} / \mathrm{yr}$ thereafter, for a total of $500 \mathrm{MT}$.

- The conversion of a similar amount of US HEU is assumed over 20 years. This is about 2 MT of HEU per month, or 40 MT of $5 \%$ U-235 per month.

- Costs associated with the purchase of Russian HEU and spot market prices for LEU will provide comparative costs for blend-down of US HEU.

\section{Economics}

The cost of any conversion of US HEU at SRS facilities should be compared with costs of alternate sources. The estimated cost of LEU for commercial reactors can be used for comparison, as well as the costs estimated for the purchase of Russian HEU.

Appendix A presents the estimate of costs to produce comparable amounts of LEU material by enrichment services. This is based on spot market prices for $\mathrm{U}_{3} \mathrm{O}_{8}$, conversion to $\mathrm{UF}_{6}$, and separative work unit (SWU) to enrich to $3.5 \%$ and 5\% U-235. Mass balance equations are also presented in Appendix A to determine material feeds required by enrichment or blend-down of HEU. As expected, the cost of producing a 5\% U-235 product by enrichment costs more than a $3.5 \%$ product due to higher SWU and material feed requirements. However, when blending down from HEU, more 3.5\% U-235 product can be made per $\mathrm{kg}$ of HEU. The trade-off between estimated commercial value per $\mathrm{kg}$ of product and $\mathrm{kg}$ of product per $\mathrm{kg}$ of HEU gives the net result that the commercial value of HEU blended down to the 3.5 to $5 \%$ U-235 range is estimated to be on the order of $\$ 15,000$ per $\mathrm{kg}$ of HEU blended.

This can be compared to early estimates of acquiring the Russian HEU. Trade journals put the cost at $\$ 82.10 /$ per SWU and about $\$ 28.50 / \mathrm{kg} \mathrm{U}$ as UF 6 (Ref. 5). The blending of $10 \mathrm{MT}$ HEU at $94 \%$ U-235 was equated to 1.8 $\times 10^{6} \mathrm{SWU}$ and about $8 \times 10^{6} \mathrm{lb}$ of $\mathrm{U}_{3} \mathrm{O}_{8}$, or $90 \times 10^{6} \mathrm{SWU}$ for $500 \mathrm{MT}$ HEU. Another reference puts $10 \mathrm{MT}$ HEU at approximately equivalent to $6 \times$ $10^{6} \mathrm{lb}$ of $\mathrm{U}_{3} \mathrm{O}_{8}$, and $1.5 \times 10^{6} \mathrm{SWU}$, assuming typical LWR enrichment and $0.30 \%$ tails asiay (Ref. 6). Using the former estimate, this would put the cost at $\left(90 \times 10^{6}\right.$ or $\left.9 \times 10^{7} \mathrm{SWU}\right)(\$ 82.10 / \mathrm{SWU})=\$ 7.39 \times 10^{9}$. On a $\$ / \mathrm{kg}$ HEU basis, this would be $\left(\$ 7.39 \times 10^{9} / 500,000 \mathrm{~kg}\right)=\$ 14,780 / \mathrm{kg} \mathrm{HEU}$. This is in good agreement with the estimates from Appendix $A$. An equivalent commercial value on the order of $\$ 1.5 \times 10^{4} \mathrm{per} \mathrm{kg}$ HEU blended will thus be used to provide the target cost for the blended material. 
The costs associated with conversion of HEU in SRS facilities will be compared to the target costs above, using a present worth cost for capital and annual operating costs over a 20-year period. This is:

present worth, $S=C+A\left[(1+i)^{n}-1\right] /\left[i(1+i)^{n}\right]$,

where

$C=$ initial capital costs, $S$

$A=$ annual operating costs, $S$

$i=$ annual interest rate

$n=$ number of years.

Interest rates ranging from $5 \%$ to $10 \% / y$ will be considered.

As for product form, note that SRS facilities as they are currently configured cannot generate a UO 2 or UF6 product. Estimates of blending costs at SRS to produce LEU in some form other than UO2 2 or UF 6 should then be adjusted to account for any additional conversion costs.

Costs associated with modifications to $S R S$ facilities to provide final conversion to $\mathrm{UO}_{2}$ or $\mathrm{UF}_{6}$ will not be made here, being beyond the scope of the study. Rather, commercial spot market prices for representative conversions will be used as a rough estimate of costs associated with any final conversion offsite from SRS needed to get the material into the proper form for input to a commercial fuel fabrication facility. Several spot market prices include $\$ 10 / \mathrm{kg}$ for conversion from $\mathrm{U}_{3} \mathrm{O}_{8}$ to $\mathrm{UF}_{6}$ (Ref. 3).

The costs associated with any final conversion of the SRS product are thus not thought to greatly alter the economics of blending at SRS.

\section{Competing US Commercial Capabilities}

In related developments, the Babcock \& Wilcox Naval Nuclear Fuel Division and Nukem formed an agreement to provide technical and financial services to DOE in the process of bringing HEU from Russia to the US for blending to LEU for use in commercial reactors (Ref. 7).

Allied Signal and Nuclear Fuel Services, Inc. (NFS) of Erwin, Tennessee, are also partners in offering blend-down capabilities (Ref. 7,op. cit.). In addition, NFS received a license amendment from the US Nuclear Regulatory Commission (NRC) to blend-down HEU to LEU. In the process, natural or slightly enriched uranium in the form of uranyl nitrate would be drawn from a large tank, through a pump, and to a tee-connection. A venturi device would then mix the blend stock with HEU, also in the form of uranyl nitrate, and deliver the product to a storage tank. Final blending to customers' specifications would occur in additional tanks. Shipment appears to be in the form of uranyl nitrate solution, in two specially constructed tank trucks (Ref. 7). 
SRS shipped enriched uranyl nitrate solution in the past, but has currently balted this practice at the order of DOE. All offsite shipments are now in the form of solids; this was the reason for construction of the Uranium Solidification Facility (USF) at H Canyon. For this reason, the consideration of uranyl nitrate solution as a final product from SRS was not considered in the original quick study. However, shipment of LEU solution via tank trucks is routinely done at NFS and other fuel fabrication sites. This opens the potential for SRS to deliver LE uranyl nitrate solution using commercial transport companies. The solution could also be shipped onsite between $\mathrm{H}$ Canyon and FA Line in F Area. Existing DOE tank trucks could be used for onsite shipments, or new commercial qualified tankers could be acquired. Both options for onsite and of fsite shipment of uranyl nitrate solutions are developed in this report. 


\section{SRS Facilities}

\section{7-F Facility}

Before development of the proposed options, the primary SRS facilities under consideration for blend-down of HEU will be introduced. The basic costs associated with the facilities will also be described, providing the basis for estimating costs of the processing options to follow. This approach is used to avoid repetition, as each option will combine the costs of operating several facilities. The only costs that need to be cited during the development of a specific option are those associated with any modifications to the basic facility costs developed here.

The intended purpose of the 247-F Facility at SRS was fabrication of HEU feedstock for nuclear fuel fabrication. This facility began operation in the mid 1980s and shut down in 1989 due to a downturn in demand for the nuclear fuel.

The feature of interest in 247-F is the storage vault used originally for receipt and storage of HEU. The vault size is consistent with the proposed receipt rate of $10 \mathrm{MT}$ HEU/yr, with potential for increasing to $30 \mathrm{MT} / \mathrm{yr}$. Materials accountability and safeguards requirements are consistent with its original intended purpose of HEU receipt and control.

Security facilities at 247-F are also consistent with proposed HEU storage. Located within the F-Area perimeter security fence, 247-F has additional security boundaries and safeguards required for its nuclear fuel fabrication program.

\section{7-F Costs}

The facility is currently in standby condition, and could be made available for immediate use. However, a potential conflict does exist for use of this facility. The program to de-inventory F Canyon plans to use the $247-\mathrm{F}$ vault for plutonium storage. An addendum to the facility Safety Analysis Report (SAR, Ref. 8) has already been submitted to DOE allowing for plutonium storage, with apparent restrictions on co-location of uranium and $\mathrm{Pu}$ for compliance with DOE Order 6430.1A (Ref. 9). Use of 247-F for HEU storage would thus be precluded under these arrangements. Additional analysis and submittal of requests for modification of current restrictions for co-location of HEU and Pu may thus be required. Alternate arrangements for storage of $\mathrm{Pu}$ inventories on site can also be explored, if need be.

The cost of equipment upgrades for $247-\mathrm{F}$ are put at $\$ 5$ million (Ref. 10 ), primarily associated with new equipment for materials accountability and safeguards. Additional costs associated with more SAR modifications and operational reviews are estimated to be $\$ 2$ million. The annual operating cost for receipt of material from $F$ Canyon have been estimated to be $\$ 12$ million/yr, and will be used here. For completeness, the surveillance and maintenance (S\&M) costs during standby are estimated at $\$ 1$ million. The cost estimates for use of 247-F for HEU storage are summarized in Table 1 below. 
Table 1. Summary of Costs Associated with 247-F

\begin{tabular}{|l|r|}
\hline Capital costs (\$ million) & 5.0 \\
Safety and operational review costs (\$ million) & 2.0 \\
Tocal capital and preparation costs (\$ million) & 7.0 \\
\hline Annual surveillance and maintenance costs (\$ million) & 1.0 \\
Annual surveillance and maintenance costs (\$ million) & 11.0 \\
Total 247-F annual estimated operating cost (\$ million) & 12.0 \\
\hline
\end{tabular}

\section{Fuel Fabrication Facility (321-M)}

\section{1-M Costs}

The bulk of all HEU reactor fuel loads for more than 40 years at SRS were fabricated in the 321-M building. HEU in the form of $93 \mathrm{wt} \% \mathrm{U}-235$ oralloy and recycled SRS HEU were blended and alloyed with aluminum by melting in an open-air melter to produce billets for extrusion into fuel tubes. In this case, 321-M would be used for blending of HEU received in the form of uranium metal. Depleted uranium (DU) metal of the required purity would be added, producing a LE uranium metal product. The facility also bas a small vault for receipt and control of HEU.

The 321-M facility is currently undergoing a campaign to de-inventory all nuclear materials. It will be available for use at the completion of this campaign, in 1995. Actual application to a blending campaign would require completion of upgrades and safety/environmental approvals and documentation. The use of 321-M for blending as metal has the advantage of simple operation, large processing rates, potential for easy expansion, and relatively low costs.

Disadvantages are that metal is not the ideal feedstock for commercial fuel fabrication, and that blending by melting cannot remove if urities in the input feedstock. It must depend on commercial-specification IEU and DU inputs. The implications of impurities are discussed further below.

For capital costs, the principal equipment required is a vacuum melter capability. The air melter used at SRS for U/Al alloys cannot be adapted for uranium metal melting. Two melters would be purchased, for redundancy and later expansion in capacity to $30 \mathrm{MT}$ HEU/yr. The original quick study assumed that a vacuum melter of sufficient capacity could be acquired at Fernald for \$0.5 million with an additional $\$ 0.5$ million installation costs. This melter is no longer available, having since been sold as surplus. A $\$ 1$ million cost per melter is estimated here, plus \$0.5 million each installation costs, for a total of $\$ 3$ million. The need for HVAC upgrades was also identified for a cost of $\$ 0.65$ million, rounded bere to $\$ 0.7$ million. Like 247-F, 321-M is assumed to require upgrades in equipment for materials accountability, also estimated to be $\$ 5$ million. Modification or upgrades to the vault for interim storage may also be required, estimated at $\$ 5$ million. The capital equipment costs then total $\$ 13.7$ million. The seismic qualification of the facility is also an issue. 
The facility is currently operating under a justification for continued operation (JCO) allowing de-inventory of materials. However, assignment to a new mission of 20-year duration would likely require an updated seismic analysis and upgrades. In the absence of any seismic analysis, the cost of potential seismic upgrades is expected to be no more than $\$ 5$ million.

For safety documentation, a significant modification of the current JCO would require a new Technical Safety Requirements document and updated facility SAR. The cost for this safety documentation and a seismic analysis is estimated at approximately $\$ 2$ million, over a two-year period.

The environmental documentation is estimated at $\$ 0.5$ million for an environmental assessment (EA) and modifications to waste water permits and waste certification plans. The facility currently operates as a Category 2 facility based on risk, and the bandling of un-irradiated HEU uranium metal is not judged to materially impact this status. These studies could again be completed in a 2-year period, contiguous with that required for the sarety documentation.

Annual operating costs scheduled during the surveillance and maintenance (S\&M) period for transition to environmental restoration (ER) are expected to be $\$ 1.5$ million/yr. The operating costs above and beyond the $S \& M$ costs are estimated at $\$ 15$ million/yr, based on past annual operating costs. Containers for storing and shipping the final LEU product will also be required. Assuming $100 \mathrm{~kg}$ of LEU metal per container, $-2,000$ containers/yr at $\$ 2,000$ each, this comes to $\$ 4$ million/yr. The melter process will also produce an annual quantity of slag, crucibles, etc., for solid waste disposal, with unrecoverable material being send to Oak Ridge. These latter costs are judged to be relatively minimal, and are not estimated bere. Total annual costs are then estimated at $\$ 20.5$ million/yr. The net estimated costs associated with use of 321-M are summarized in Table 2 below.

Table 2. Summary of Costs Associated with 321-M

\begin{tabular}{|c|c|}
\hline Equipment ( $\$$ million) & 13.7 \\
\hline Facility seismic upgrades ( $\$$ million) & 5.0 \\
\hline Environmental documentation costs ( $\$$ million) & 0.5 \\
\hline Safety and operational review costs ( $\$$ million) & 2.0 \\
\hline Total capital and preparation costs ( $\mathbf{S}$ million) & 21.2 \\
\hline Annual cost for shipping/storage containers ( $\$$ million) & 4.0 \\
\hline Annual surveillance and maintenance costs ( $\$$ million) & 1.5 \\
\hline Annual operating costs ( $\$$ million) & 15.0 \\
\hline Annual estimated operating costs, total ( $\$$ million) & 20.5 \\
\hline
\end{tabular}




\section{$F$ and $H$ Canyons $(221 F, 221-H)$}

The F and $\mathrm{H}$ Canyons at SRS are designed for processing irradiated targets and fuel, to separate and recover plutonium and uranium, respectively. In the case of uranium processing, input stoci of metal or oxide will be dissolved in nitric acid, producing a uranyl nitrate solution. The solution can be passed to a uranium solvent extraction cycle for removal of impurities and adjustment of chemistry, as required. Both canyons were originally designed to recover plutonium from irradiated natural uranium. However, H-Canyon was modified to process enriched uranium fuels (Ref. 11).

The canyons can dissolve metal or oxides. At F Canyon, the uranyl nitrate from dissolution or the solvent extraction cycle can be passed to the FA Line denitrators, producing $\mathrm{UO}_{3}$ powder. At $\mathrm{H}$ Canyon, the $\mathrm{A}$ Line was disassembled in the 1960s. Although H Canyon is the preferred option for processing of enriched uranium, rebuilding an A Line capability for the purposes of this program is not considered a viable option. A Uranium Solidification Facility (USF) nearing completion in $\mathrm{H}$ Area will convert uranyl nitrate to $\mathrm{UO}_{3}$. However, the capacity of the USF continuous denitrator iimits throughput to approximately $8 \mathrm{MT}$ of $\mathrm{HE}$ oxide per year, or $160 \mathrm{MT}$ over a 20-year campaign. With 5\% U-235 LE uranyl nitrate feed, a more concentrated uranium content (i.e., $>200$ gms U/liter) can increase the USF throughput by an estimated factor of -4.2 to $33.6 \mathrm{MT} / \mathrm{yr}$ or $672 \mathrm{MT}$ of LE oxide powder over 20 years; however, this consumes only $-34.8 \mathrm{MT}$ of HEU in the process. The H-Canyon, USF option is thus not viable for conversion of the entire $500 \mathrm{MT}$ HEU assumed, but may be viable for smaller conversion campaigns.

Uranyl nitrate solution as a final product form was not considered in the initial quick study. Transportation of HE uranyl nitrate solution from SRS to Oak Ridge did occur in the past, but was eliminated by DOE directive, which was the primary reason for construction of the USF. However, commercial transportation facilities appear to be available nationally for shipment of LEU solutions (Ref. 6), indicating that direct shipment of LE uranyl nitrate solution from $\mathrm{H}$ or $\mathrm{F}$ Canyon is a viable option. Commercial tank trucks would be loaded onsite, at which point the commercial vendor would take responsibility for offsite shipment to a commercial fuel fabrication facility. Another option would be to ship LE uranyl nitrate solution from $\mathrm{H}$ Canyon to FA Line in $\mathrm{F}$ Area for denitrating to $\mathrm{UO}_{3}$ powder.

\section{F-Canyon and FA-Line Costs}

The costs associated with production of $\mathrm{LEU} \mathrm{UO}_{3}$ powder from processing in F Canyon and denitrating in FA Line will be used as representative of canyon operation at SRS. Dissolution of HEU in F Canyon would require some equipment modification. Capital costs for equipment (Ref. 10) are summarized in Table 3. 
Table 3. Capital Equipment for F Canyon

\begin{tabular}{|l|r|c|}
\hline Item & Quantity & $\begin{array}{l}\text { Cost } \\
\text { (Smillion) }\end{array}$ \\
\hline 1. Modifications to dissolvers & 3 & 5.0 \\
2. Modification of feed tanks and piping & 2 & 2.5 \\
3. Modification of unloading facility and onsite transfer & 1 & 5.0 \\
4. Modification of jumper and jumper piping & 130 & 3.5 \\
5. Dissolver vacuum pump and piping & 1 & 2.5 \\
6. 221-F dissolver & 1 & 1.0 \\
7. 221-F dissolver vacuum pump and piping & 1 & 0.5 \\
8. Mndifications to 221-F denitrator & 3 & 2.0 \\
9. Modifications to 22.-F drum-loading facility & 1 & 4.0 \\
\hline Total capital cost & & 27.0 \\
\hline
\end{tabular}

For safety and environmental documentation, the items shown below in Table 4 have been identified (Ref. 12) and estimated.

The annual operating cost was estimated to be \$21 million in excess of those associated with the surveillance and maintenance (S\&M) period for transition to environmental restoration (ER) (Ref. 10). Annual operating costs for F Canyon from the SRS 5-year plan (Ref. 13) are as follows:

- FY 93, 567 million

- FY 94, $\$ 55$ million

- FY 95, $\$ 58$ million

- FY 96, $\$ 54$ million

- FY 97, $\$ 44$ million

- FY 98, $\$ 41$ million

- FY 99, $\$ 36$ million

The costs for FY 94 and 95 are considered representative of operational costs, where $\$ 36$ million in FY 99 is considered representative of costs as the facility enters a period of S\&M. The $\$ 21$ million estimate is considered consistent with projecting a relatively flat total operational cost of $(\$ 36$ million $+\$ 21$ million $)=\$ 57$ million beyond FY 95 .

The net estimated costs associated with use of $221-\mathrm{F}$ are summarized below in Table 5. 
Table 4. Safety and Environmental Studies for F-Canyon

\begin{tabular}{|c|c|}
\hline $\begin{array}{l}\text { Item } \\
\text { 1. Nuclear Criticality Safety Analysis (NCSA)-required to establish a safe mass of U-235 } \\
\text { that may be charged to each port of the annular dissolver. } \\
\text { 2. NCSA of FA Line-required to establish criteria for safe handling of uranium solutions } \\
\text { and uranium trioxide in the FA Line containing up to } 5 \text { wt\% U-235. } \\
\text { 3. Test Authorization and Unreviewed Safety Question Determination (USQD) must be } \\
\text { prepared and approved by WSRC \& DOE management. } \\
\text { 4. Safety Analysis Report-a revision or new SAR would need to be prepared and approved } \\
\text { by WSRC, DOE/SR an DOE HQ to authorize processing of uranium containing greater } \\
\text { than } 1 \text { wt\% } 235-U \text { in F Canyon and FA Line. } \\
\text { 5. Technical Safety Requirements (formerly Operating Safety Requirements) would be } \\
\text { required to operate all process equipment. DOE Headquarters approval would be } \\
\text { requiredfor these documents. } \\
\text { 6. Security and Safeguard Issues-Concerns for F Canyon to transport, handle, and charge } \\
\text { HEU will need to be addressed very early so all issues can be resolved and documented. } \\
\text { This was a big problem when processing plutonium metal in F Canyon and is anticipated } \\
\text { to be bave very similar concerns with processing HEU metal. } \\
\text { 7. Modification of F-Canyon Transition Plan-The plan to move from Operaing Status to } \\
\text { Environmental Restoration and Waste Management Status will be delayed. The initial step } \\
\text { of this process (Phaseout Plan) is scheduled to be completed by } 10 / 95 ; \text { this Plan has been } \\
\text { approved by WSRC and DOE-SR and is currently awaiting DOE-Headquarters approval. } \\
\text { 8. Environmental Impact Statement (EIS)-underway } \\
\text { Total safety and envimnmental documentation costs }\end{array}$ & 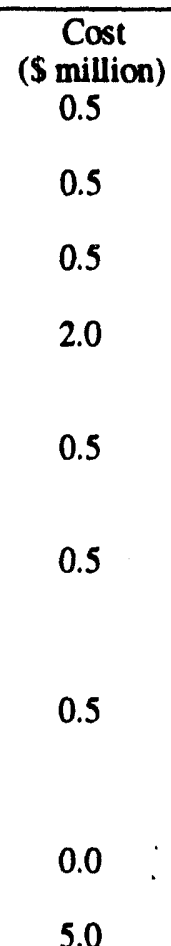 \\
\hline
\end{tabular}

Table 5. Summary of Costs Assoclated with 221-F

\begin{tabular}{|c|r|}
\hline Capital costs (\$ million) & 27.0 \\
Safety and environmental documentations costs (\$ million) & 5.0 \\
Capital and preparation costs, total (\$ million) & 32.0 \\
\hline Annual surveillance and maintenance costs (\$ million) & 36.0 \\
Other annual operating costs (\$ million) & 21.0 \\
Estimated annual operating costs, total (Smillion) & 57.0 \\
\hline
\end{tabular}




\section{Related Issues}

Several issues related to impurities and requirements for LEU fuel for use in commercial reactors may affect the processing options considered here. These need to be clarified before discussion of processing options at SRS.

\section{Uranium Isotopic Impurities}

The uranium isotopic content of the HEU was not specified by DOE. The typical content of SRS recycle and virgin HEU are given in Table 6 below for reference (Ref. 14). The ASTM Standard C 996 (Ref. 15) specifies the uranium isotopic limits for commercial fuel in oxide shown in Table 7 below.

As can be seen, the U-234 content of typical 93 wt\% HEU used at SRS exceeds the ASTM standard by $34 \%$. The U-236 content is outside specifications, but within the upper range where reporting of U-232 and Tc99 content are required, so the buyer can evaluate the economic penalty for use in a commercial power plant.

Table 6. Typical HE Uranium Isotopic Content

\begin{tabular}{|c|c|c|c|c|}
\hline Isotope & SRS HE & J-235 & SRS HEU 93 wt & -235 \\
\hline & units & $\mu \mathrm{g} / \mathrm{g}$ U-235 & units & $\mu \mathrm{g} / \mathrm{g} U-225$ \\
\hline $\mathrm{U}-232$ & $20 \mathrm{ppb}$ & 0.02 & & \\
\hline U-233 & $10 \mathrm{ppm}$ & 10 & & 13,400 \\
\hline U-234 & $1.5 w t \%$ & 18,800 & $1.25 w t \%$ & 13,400 \\
\hline U-235 & $80 w t \%$ & $1 \times 10^{6}$ & $93 w t \%$ & $1 \times 10^{6}$ \\
\hline U-236 & $11 w t \%$ & $1.38 \times 10^{5}$ & $0.75 w t \%$ & 8060 \\
\hline U.238 & $7.5 w t \%$ & $9.38 \times 10^{4}$ & $6.0 w 1 \%$ & $6.45 \times 10^{4}$ \\
\hline
\end{tabular}

Table 7. ASTM Specification for Uranium Isotopic Impurities

\begin{tabular}{|l|l|}
\hline Isotope & $\mu \mathrm{g} / \mathrm{g} \mathrm{U}-235$ \\
$\mathrm{U}-232$ & 0.0002 \\
$\mathrm{U}-234$ & $10,000^{\mathrm{a}}$ \\
$\mathrm{U}-236$ & $5,000^{\mathrm{b}}$ \\
\hline
\end{tabular}

aU-234 levels as high as $11,000 \mu \mathrm{g} / \mathrm{g}$ U-235 are allowed for in the ASTM spec given advanced negotiation.

b The buyer may base acceptance for suitability in fuel fabrication on the total significance of all measured levels of radionuclides. If U-236 levels are greater than $5,000 \mu \mathrm{g} / \mathrm{g}$ U-235, then measurements of U-232 and Tc-99 are required. 
The U-236 content in typical $80 w t \%$ U-235 recycle at SRS exceeds the ASTM specifications by over an order of magnitude. Bringing it back into specifications would require blending with additional sources of relatively clean U-235. The alternative again is an evaluation of the economic penalty associated with its use in a commercial plant, and an adjustment in the final worth.

\section{DU Feedstock and Commercial Fuel Specifications}

With the assumed 93 wt\% HEU isotopic content listed above, the blenddown would require 18.33 and $27.12 \mathrm{~kg}$ of DU per $\mathrm{kg}$ of HEU to reach 5 $w t \%$ and $3.5 w t \%$ U-235, respectively (Table A.2, Appendix A). A campaign to blend down $500 \mathrm{MT}$ of HEU would then require 9,165 or $13,560 \mathrm{MT}$ of DU for $5 w t \%$ and $3.5 w t \%$ U-235, respectively.

In this study it has been assumed that existing stores of purified depleted uranium oxide or metal would be used whenever possible. SRS currently bas approximately $19,500 \mathrm{MT}$ DU in the form of $\mathrm{UO}_{3}$ stockpiled at the site (Ref. 16), and 2,600 MT DU in the form of metal. The $\mathrm{SRS} \mathrm{UO}_{3}$ is thus sufficient for options involving dissolution in the canyons.

The metal DU stockpile is, bowever, insufficient for the entire campaign. At the rate of $10 \mathrm{MT} / \mathrm{yr}$ for the first 5 years, the stock would be depleted at the rate of $183.3 \mathrm{MT}$ DU/yr per $10 \mathrm{MT}$ HEU. If after 5 years the blend-down rate increases to $30 \mathrm{MT} / \mathrm{yr}$, and the depletion rate increases to $549.9 \mathrm{MT} \mathrm{DU} / \mathrm{yr}$. On this schedule, the SRS metal DU stockpile would be exhausted in approximately 8 years. An additional $(9,270-2,600)=6,670 \mathrm{MT}$ DU would be required to complete the campaign.

The referenced DOE memorandum (Ref. 1) listed a number of LEU materials that are available to blend with the HEU, totaling on the order of 4,500 MTU. This would still be insufficient. Commercial sources would have to be investigated, likely relying on conversion of $\mathrm{UF}_{6}$ from the DU stockpiles at Oak Ridge. Costs associated with acquisition of additional DU metal for the 321-M melting option were not developed in this report.

Note that the referenced DOE memorandum (Ref. 1) also indicated that a significant portion of the DU stock may be alloyed with impurities. The exact chemical composition was not cited in detail. However, the presence of impurities would require the evaluation of the feedstock with respect to commercial nuclear fuel standards published by the ASTM (Ref. 15, 17, and 18 for $\mathrm{UO}_{2}, \mathrm{UF}_{6}$, or uranyl nitrate solution, respectively). Processing in the SRS canyons could remove the impurities; however, the melting option in $321-\mathrm{M}$ would carry over all impurities in the feedstock into the final metal product. The following scenarios and implications would apply to the $321-\mathrm{M}$ melting option if DOE directs the use of existing complex stocks of DU metal:

- If analysis shows that impurity levels are unacceptable for commercial fuel, the 321-M option at SRS would be eliminated.

- If analysis shows that impurity levels are acceptable to commercial fuel, there still may be an impact on the commercial market value of the final product (i.e., cost penalties for impurities). 
A full analysis of the viability of the 321-M option at SRS must thus await a more definitive statement from DOE on the use of existing alloyed DU metal feedstock, and a complete analysis of the chemicy composition of those alloys. Only then can the potential impact on acceptance for use in commercial nuclear fuel be evaluated. 


\section{Operating Scenarios}

The task team in the original quick study identified six processing options that appear to meet most or all objectives of the request. In all the options, the HEU metal feedstock would be received into the 247-F Facility, weighed for accountability if necessary, and stored in the 247-F vault. The $321-\mathrm{M}$ vault could be an alternate, and could be used if additional capacity were needed. These vaults meet safeguards and nuclear criticality safety control requirements. As discussed above for 321-M, the seismic design of these vaults is now being assessed for another program to verify that they meet current design requ:irements.

Since the original quick study, the potential for direct shipment of LE uranyl nitrate solution at SRS has been raised. Options 2 and 3 addressing this potential have been added, producing 8 options to be considered, as listed below. Note that the options are in two groups: those considered most feasible in meeting DOE's progammatic needs, and those that are feasible, but judged to be less favorable from a cost and technical perspective. The results of the analysis for the former group only are included in the Summary section of this report.

All potential options, including those considered less feasible due to technical or economic limitations, will be developed here for completeness.

More feasible options for blend-down of 500 MT HEU at SRS facilities:

1. 321-M makes LE uranium metal

2. 221-F makes $\mathrm{LE} \mathrm{UO} 3$ powder

3. 221-F or $\mathrm{H}$ makes $\mathrm{LE}$ uranyl nitrate solution for shipment offsite

4. 221-H makes LE uranyl nitrate, shipped to $\mathrm{FA}$ Line making $\mathrm{UO}_{3}$ powder

Less feasible options for blend-down of $500 \mathrm{MT}$ HEU at SRS facilities:

5. 221-H makesg LE uranyl nitrate, making LE $\mathrm{UO}_{3}$ powder in USF (limited only by USF capacity)

6. 221-H, USF, makes $\mathrm{HE} \mathrm{UO}_{3}$, mechanical blending to $\mathrm{LE} \mathrm{UO}_{3}$ in 247 $\mathbf{F}$

7. 321-M, LEU metal to 221-F, dissolve making $\mathrm{LE} \mathrm{UO} 3$ powder

8. 321-M, LEU metal to 221-H, dissolve, making LE UO 3 powder in USF

\section{Option 1.}

\section{1-M Making LE Metal}

This option assumes that no impurities must be removed in the blending process, and that metal uranium product is acceptable. The steps include:

- HEU feedstock is received, accounted for, and stored in vaults in 247-F.

- The HEU feedstock is transported to $321-\mathrm{M}$, where it is melted and blended with molten depleted uranium metal in an inert gas induction furnace.

- The molten LEU metal at $<5 \%$ U-235 is poured into ingots to be sampled and weighed for accountability, stored onsite, then transported 
to its final destination (likely under control of the US Enrichment Corporation).

Costs for this option using $247-\mathrm{F}$ and $321-\mathrm{M}$ are summarized in Table 8.

Table 8. Summary of Costs Associated with Option 1

\begin{tabular}{|l|r|}
\hline Capital costs, (S million) & 23.7 \\
$247-F$ & 5.0 \\
$321-\mathrm{M}$ & 18.7 \\
Safety and environmental studies costs, (S million) & 4.5 \\
$247 . \mathrm{F}$ & 2.0 \\
$321-\mathrm{M}$ & 2.5 \\
Total capital and preparation costs (S million) & 28.2 \\
\hline Surveillance and maintenance costs (u million) & 2.5 \\
$247 . \mathrm{F}$ & 1.0 \\
$321-\mathrm{M}$ & 1.5 \\
Annual operating costs above S\&M (S million) & 30.0 \\
$247-\mathrm{F}$ & 11.0 \\
$321-\mathrm{M} \quad$ Total annual operating costs (S million) & 32.5 \\
\hline
\end{tabular}

With capital, $C$, annual operating costs, $A$, and annual interest rate, $i$, for $n=20$ years, the present worth, $S=C+A\left[(1+i)^{n}-1\right] /\left[i(1+i)^{n}\right]$, is then given below for this option for interest rates ranging from $5 \%$ to $10 \% / y r$. Also given is the resulting $\$ / \mathrm{kg}$ HEU, derived by dividing the present worth (PW) by the assumed $500,000 \mathrm{~kg}$ of HEU (Table 9). As can be seen, this option compares favorably to the target cost of $\$ 1.5 \times 10^{4} / \mathrm{kg}$ for conversion of $500 \mathrm{MT}$ HEU.

Table 9. Present Worth for Option $1, n=20$ yrs

\begin{tabular}{|c|c|c|}
\hline Interest rate & PW (S million) & S/kg HEU \\
\hline $10 \%$ & 305 & 610 \\
$9 \%$ & 325 & 650 \\
$8 \%$ & 347 & 695 \\
$7 \%$ & 373 & 745 \\
$6 \%$ & 401 & 802 \\
$5 \%$ & 433 & 866 \\
\hline
\end{tabular}




\section{Option 2. 221f Canyon, FA Line Making LE UO3 Powder}

In this option, HEU feedstock is simultaneously dissolved and blended to $<5 \%$ U-235 in 221-F. It would be processed through one cycle of solvent extraction to purify it and adjust acidity, and then be transferred to the FALine facility (outside 221-F) for conversion to $\mathrm{LE} \mathrm{UO}_{3}$ powder in continuous denitrators. This option has the advantage of ensuring a pure product regardless of the purity of foedstock. It could include the DU feedstocks identified in the original DOE request (Ref. 1), although tine preferred course of action would be to use the large inventory of depleted $\mathrm{UO}_{3}$ powder existing in SRS stockpiles.

The steps for this option are then as follows:

- HEU feedstock is received, accounted for, and stored in the 247-F vault.

- The HEU feedstock is transported to 221-F, where it is simultaneously dissolved and blended with DU. Cost estimates assume dissolving will occur in two dissolver vessels, and a third vessel will be modified as a spare. The HEU metal is placed in reusable stainless steel baskets for dissolving in a nitric acid solution that contains sufficient depleted uranium (from dissolved depleted $\mathrm{UO}_{3}$ ) to produce a uranium blend of $<5 \%$ U-235. Because of nuclear criticality safety limits, the concentration of total $U$ at $5 \%$ U-235 must be kept below about 280 grams per liter (Ref. 19), and the amount of HEU solid metal in the dissolver basket at any one time is limited, which limits the total dissolving rate.

- The dissolver solution of LE uranyl nitrate is processed through the second uranium solvent extraction cycle to purify and concentrate the uranium and reduce the acidity.

- The solution is then processed through FA Line's evaporator and continuous denitrators producing $\mathrm{LE} \mathrm{UO} 3$, which is packaged in sealed drums for accountability, storage, and transport.

- The drums will be stored temporarily onsite before being transported to the final storage site or fuel fabricator.

Costs for this option using 247-F and 221-F are summarized in Table 10. 
Table 10. Summary of Costs Associated with Option 2

\begin{tabular}{|l|r|}
\hline Capital costs (\$ million) & 32.0 \\
247-F & 5.0 \\
221-F & 27.0 \\
Safety and environmental studies costs (\$ million) & 7.0 \\
247-F & 2.0 \\
221-F & 5.0 \\
Total capital and preparation costs (\$ million) & 39.0 \\
\hline Surveillance and maintenance costs (\$ million) & 37.0 \\
247-F & 1.0 \\
221-F & 36.0 \\
Annual operating costs above S\&M (\$ million) & 32.0 \\
247-F & 11.0 \\
221-F & 21.0 \\
\multicolumn{2}{r}{ Total annual operating costs (\$ million) } \\
\hline
\end{tabular}

The estimate of present worth based on the costs above is then given in Table 11. The resulting $\$ / \mathbf{k g}$ HEU processed is also again given, assuming 500,000 kg of HEU. This option also compares favorably to the target cost of $\$ 1.5 \times$ $10^{4} / \mathrm{kg}$ for conversion of $500 \mathrm{MT}$ HEU, but only for assumed higher annual interest rates (i.e., $\mathrm{i} \geq \mathbf{8 \%} / \mathrm{yr}$ ).

Table 11. Present Worth for Option 2, $n=20$ yrs

\begin{tabular}{|c|c|c|}
\hline Interest rate & PW (\$ million) & \$/kg HEU \\
\hline $10 \%$ & 626 & 1253 \\
$9 \%$ & 669 & 1338 \\
$8 \%$ & 716 & 1433 \\
$7 \%$ & 770 & 1540 \\
$6 \%$ & 830 & 1661 \\
$5 \%$ & 899 & 1798 \\
\hline
\end{tabular}

\section{Option 3. 221-F or 221-H Making LE Uranyl Nitrate Solution for Shipment Offsite}

As discussed earlier, this option was not considered in the original quick study. Indications are however that commercial NRC and DOT licensed tank trucks are available to ship LE uranyl nitrate solution. Past practice at SRS was to pump the uranyl nitrate solution from the canyon to tanks outside the canyon for storage and loading into tank trucks. Note that $221-\mathrm{H}$ can also be 
used here as representative of the concept, although exact $\mathrm{H}$-Canyon costs would differ somewhat.

As with Option 2 above, HEU would be received and stored at 247-F and shipped to the canyon for dissolution and isotopic blending. The dissolver solution is then processed through the second uranium solvent extraction cycle. The new steps associated with this option will be as follows:

- The LE uranyl nitrate from the dissolver or extraction cycle is pumped to bolding tank(s) outside the canyon.

- The LE uranyl nitrate is pumped from the holding tank to commercial tank trucks for shipment offsite to a commercial fuel fabrication facility or a storage facility.

The costs associated with operation of 221-F outlined previously will be adjusted for elimination of the FA-Line capital improvements (\$7.5 million) and safety studies ( $\$ 0.5$ million). The need to perform a more extensive EIS is estimated to add \$2 million. The annual incremental operating costs above surveillance and maintenance (S\&M) are also estimated to drop by $1 / 3$ (\$7) million), due to not needing FA-Line operation. The adjusted costs are then shown in Table 12.

Tahle 12. Summary of Costs Associated with 221-F. L trangl Nitrate Proxluct

\begin{tabular}{|r|r|}
\hline Capital costs (\$ million; 27 - 7.5) & 19.5 \\
Safety and environmental costs (\$ million; $5+2$ - 0.5) & 6.5 \\
Total capital and preparation costs (\$ million) & 26.0 \\
\hline Surveillance and maintenance costs (\$ million) & 36.0 \\
Annual operating costs above S\&M (\$ million; 21 - 7) & 14.0 \\
Total annual operating costs (\$ million) & 50.0 \\
\hline
\end{tabular}

Costs for this option including the use of 247-F are summarized in Table 13. 
Table 13. Summary of Costs Associated with Option 3

\begin{tabular}{|c|c|}
\hline Capital costs, ( $\$$ million) & 24.5 \\
\hline 247-F & 5.0 \\
\hline 221-F & 19.5 \\
\hline Safety and environmental studies costs, ( $\$$ million) & 8.5 \\
\hline $247-F$ & 2.0 \\
\hline 221-F & 6.5 \\
\hline Total capital and preparation costs ( $\$$ million) & 33.0 \\
\hline Surveillance and maintenance costs ( $\$$ million) & 37.0 \\
\hline 247-F & 1.0 \\
\hline $221-\mathbf{F}$ & 36.0 \\
\hline Annual operating costs above S\&M (\$ million) & 25.0 \\
\hline $247-\mathrm{F}$ & 11.0 \\
\hline $221-\mathrm{F}$ & 14.0 \\
\hline Total annual operating costs ( $\mathbf{S}$ million) & 62.0 \\
\hline
\end{tabular}

The estimate of present worth (see Table 14) and resulting S/kg HEU are given, assuming $500,000 \mathrm{~kg}$ of HEU. The economics of this option are slightly improved over Option 2, and compare favorably to the target cost of $\$ 1.5 \times 10^{4} / \mathrm{kg}$ for conversion of $500 \mathrm{MT}$ HEU.

Table 14. Present Worth for Option 3, $n=20$ yrs

\begin{tabular}{|c|c|c|}
\hline Interest rate & PW (\$ million) & S/kg HEU \\
\hline $10 \%$ & 561 & 1122 \\
$9 \%$ & 599 & 1198 \\
$8 \%$ & 642 & 1283 \\
$7 \%$ & 690 & 1380 \\
$6 \%$ & 744 & 1488 \\
$5 \%$ & 806 & 1611 \\
\hline
\end{tabular}

\section{Option 4. 221-H LE Uranyl Nitrate Shipped to FA Line Making LE UO3 Powder}

This option considers the traditional use of $\mathrm{H}$ Canyon for processing highly enriched fuels, coupled with the FA Line in F Area for final conversion to UO3 powder. The steps are as follows:

- The HEU metal is placed in reusable stainless steel baskets for dissolving in nitric acid. 
- The dissolver solution of HE uranyl nitrate solution is processed through the second uranium solvent extraction cycle to purify the uranium and adjust acidity. It is then transferred to the 150,000-gallon USF storage tank outside the $\mathrm{H}$ Canyon.

- A measured amount of depleted uranyl nitrate solution, prepared by dissolving purified DU trioxide or metal, is transferred to the USF storage tank, isotopically diluting the tank inventory.

- The LE uranyl nitrate is transferred to an approved tank truck for shipment to FA Line.

- The LE uranyl nitrate is processed through FA Line's continuous evaporator and denitrator producing $\mathrm{LE} \mathrm{UO} 3$, which is packaged for accountability, storage, and transport to a fuel fabricator or storage site.

For completeness, the costs will be estimated here. In this case, the capital costs will be divided between the dissolution and extraction phase (\$19.5 million) associated with $221-\mathrm{H}$, and the denitrating costs for FA Line, put at $\$ 7.5$ million. The safety and environmental costs of \$5 million from Option 2 were reduced by $\$ 0.5$ million in Option 4 to reflect no need for analysis of FA Line, but increased $\$ 2$ million for transportation studies. The resulting $\$ 6.5$ million will be applied to $221-\mathrm{H}$ in this case. The original $\$ 5$ million for safety and environmental studies for 221-F will be reduced by the $\$ 0.5$ million estimate for criticality analysis of the dissolver, for $\$ 5.5$ million. The annual operating costs of $\$ 21$ million above surveillance and maintenance (S\&M) costs from Option 2 will be divided with $\$ 14$ million going to dissolution and extraction in $221-\mathrm{H}$, and $\$ 7$ million going to FA Line. The cost estimates are then as shown in Table 15.

Table 15. Summary of Costs Associated with Option 4

\begin{tabular}{|l|r|}
\hline Capital costs (\$ million) & 32.0 \\
247-F & 5.0 \\
221-H & 19.5 \\
FA Line & 7.5 \\
Safety and environmental studies costs (\$ million) & 13.1 \\
247-F & 2.0 \\
221-H & 6.5 \\
FA Line & 4.5 \\
Total capital and preparation costs (\$ million) & 45.0 \\
\hline Surveillance and maintenance costs (\$ million) & 37.0 \\
247-F & 1.0 \\
221-H and FA Line & 36.0 \\
Annual operating costs above S\&M (\$ million) & 32.0 \\
247.F & 11.0 \\
221-H & 14.0 \\
FA Line & 7.0 \\
& Total annual operating costs (\$ million) \\
\hline
\end{tabular}


The estimate of present worth (see Table 16) and resulting $\$ / \mathrm{kg}$ HEU are given, assuming $500,000 \mathrm{~kg}$ of HEU. as expected, the economics of this option do not compare favorably to those of Option 2, where oxide product can be made in F Canyon alone.

Table 16. Present Worth for Option 4, $n=20 \mathrm{yrs}$

\begin{tabular}{|c|l|l|}
\hline Interest rate & PW, S million & S/kg HEU \\
$10 \%$ & 632 & 1265 \\
$9 \%$ & 675 & 1350 \\
$8 \%$ & 722 & 1445 \\
$7 \%$ & 776 & 1552 \\
$6 \%$ & 836 & 1673 \\
$5 \%$ & 905 & 1810 \\
\hline
\end{tabular}

\section{Option 5. 221-H, Uranium Solidification Facility (USF) Making LE $\mathrm{UO}_{3}$ Powder}

As described earlier, the original A-Line function of evaporation and denitrating was removed from $H$ Area in the 1960 s. A Uranium Solidification Facility (USF) is being added to $\mathrm{H}$ Area to provide a similar function for HEU, although at a reduced capacity. The USF throughput is about $8 \mathrm{MT} / \mathrm{yr}$, assuming a uranium concentration in the uranyl nitrate solution of $7 \mathrm{gm}$ HEU/liter. When processing LEU, the solution concentration can increase to about $220 \mathrm{gm}$ U/hiter. The reduced evaporation requirements increase the estimated throughput by a factor of 4.2 to $33.6 \mathrm{MT} / \mathrm{yr}$ or $672 \mathrm{MT}$ of $\mathrm{LE} \mathrm{UO}_{3}$ powder in 20 years. However, the effective HEU processing rate is still reduced over the HEU processing rate. From Appendix A, this equates to $(672 /(18.33+1)=34.8 \mathrm{MT}$ of HEU blended at $5 \% \mathrm{U}-235$, and $(672 /(27.12+$ 1) $=23.9 \mathrm{MT}$ of HEU blended at $3.5 \%$ U-235 over a 20 -year period. The USF would then process at most $34.8 / 500=7 \%$ of the total $500 \mathrm{MT}$ goal for the program. This option thus does not meet the specified throughput rate, but will be presented for completeness, as the USF option may be of interest for smaller throughput campaigns. This may be especially true for processing HEU in the USF, where the throughput would remain at the rated $8 \mathrm{MT}$ oxide/yr, or $160 \mathrm{MT}$ of $\mathrm{HE} \mathrm{UO}_{3}$ powder over 20 years. This will be explored further in Option 6 below. The steps involved in producing $L E \mathrm{UO}_{3}$ powder in USF are then as follows:

- HEU would be received and stored at 247-F and shipped to 221-H

- HEU feedstock is dissolved in $221-\mathrm{H}$ in reusable stainless steel baskets using nitric acid.

- The dissolved HEU solution is processed through the H-Canyon second uranium solvent extraction cycle to purify the uranium and adjust acidity.

- The solution is then transferred to the USF feed storage tank where it is blended down to $<5 \%$ U-235. It is then processed through USFs evaporator and denitrator producing $\mathrm{LE} \mathrm{UO}_{3}$ powder, which is 
packaged into sealed canisters for accountability, storage, and transport to the storage location.

The capital equipment costs associated with $F$ Canyon will be used as an estinate for use of $\mathrm{H}$ Canyon, minus the costs associated with FA Line as was done with Option 4 above. The equipment costs are then put at (27 - 7.5) $=\$ 19.5$ million, and the safety and environmental study costs are put at (5. $0.5)=\$ 4.5$ million.

Annual operating costs for H Canyon from the SRS 5-year plan (Ref. 13) are as follows:

- FY 93, $\$ 67$ million

- FY 94, \$64 million

- FY 95, $\$ 64$ million

- FY 96, $\$ 65$ million

- FY 97, \$61 million

- FY 98, $\$ 59$ million

- FY 99, $\$ 55$ million

The schedule for $\mathrm{H}$ Canyon to enter into an surveillance and maintenance phase is delayed several years beyond $\mathrm{F}$ Canyon. It is assumed that $\mathrm{H}$ Canyon S\&M costs will approach those of F Canyon beyond FY99. The same estimate of \$36 million for S\&M and \$21 million additional cost for full operational status will be made here. The modified costs for $\mathrm{H}$ Canyon will be summarized, then added to the total for all facilities used in this option in Tables 17 and 18.

Table 17. Summary of Costs for 221-H, USF LEU UO3 Power Product

\begin{tabular}{|l|r|}
\hline Capital costs (\$ million) & 19.5 \\
Safety and environmental costs (\$ million) & 4.5 \\
Total capital and preparation costs (\$ million) & 24.0 \\
\hline Annual surveillance and maintenance costs (\$ million) & 36.0 \\
Annual operating costs above S\&M (\$ million) & 21.0 \\
Total annual operating costs (\$ million) & 56.0 \\
\hline
\end{tabular}

Costs for this option including the use of 247-F are summarized as follows: 
Table 18. Summary of Costs Associated with Option 5

\begin{tabular}{|l|r|}
\hline Capital costs (\$ million) & 24.5 \\
$247-\mathrm{F}$ & 5.0 \\
$221 \cdot \mathrm{H}$ & 19.5 \\
Safety and environmental studies costs (\$ million) & 6.5 \\
$247-\mathrm{F}$ & 2.0 \\
$221 \cdot \mathrm{H}$ & 4.5 \\
Total capital and preparation costs (\$ million) & 31.0 \\
\hline Surveillance and maintenance costs (\$ million) & 37.0 \\
$247 \cdot \mathrm{F}$ & 1.0 \\
$221 \cdot \mathrm{H}$ & 36.0 \\
Annual operating costs above S\&M (\$ million) & 32.0 \\
$247 \cdot \mathrm{F}$ & 11.0 \\
$221 \cdot \mathrm{H} \quad 21.0$ \\
\multicolumn{2}{|c|}{ Total annual operating costs (\$ million) } \\
\hline
\end{tabular}

The estimate of present worth (see Table 19) and resulting \$/kg HEU are given, assuming $34.8 \mathrm{MT}$ of HEU equivalent processed over 20 years. As expected, this low throughput makes the effective $\$ / k g$ HEU cost highly noncompetitive with the target cost of $\$ 1.5 \times 10^{4} / \mathrm{kg}$ for conversion of $500 \mathrm{MT}$ HEU.

Table 19. Present Worth for Option $5, n=20$ yrs

\begin{tabular}{|c|l|l|}
\hline Interest rate & PW, S million & \$/kg HEU* \\
$10 \%$ & 618 & 17771 \\
$9 \%$ & 661 & 18991 \\
$8 \%$ & 708 & 20358 \\
$7 \%$ & 762 & 21896 \\
$6 \%$ & 822 & 23633 \\
$5 \%$ & 891 & 25600 \\
\hline
\end{tabular}

* The capacity of the USF limits processing to $34.8 \mathrm{MT}$ total HEU equivalent over 20 years. 


\section{Option 6. 221-H, USF, Making $\mathrm{HE} \mathrm{UO}_{3}$, Mechanical Blending to $\mathrm{LE} \quad \mathrm{UO}_{3}$ in $247-\mathrm{F}$}

This option differs from those above in that no blend-down of the HEU occurs during canyon processing. 221-H will produce high enriched (HE) uranyl nitrate, for conversion to $\mathrm{HE} \mathrm{U_{3 }}$ powder in the USF. This significantly improves the capacity of USF when measured in MT/yr HEU equivalent, giving a $1 \mathrm{MT} / \mathrm{mo}$ or $12 \mathrm{MT} / \mathrm{yr}$ capacity for HEU equivalent. (Note that actual USF capacity for normal operation could be expected to be about half this rate, or $0.5 \mathrm{MT} / \mathrm{mo}$ ).

The steps for this option are then as follows:

- HEU feedstock is received, accounted for, and stored in 247-F.

- The HEU feedstock is transported to 221-H for dissolution and processing through the second uranium extraction cycle.

- The highly enriched uranyl nitrate solution is then transferred to the USF feed storage tank.

- It is then processed through USF's evaporator and denitrator producing HE UO3. The expected processing rate is again about $1.0 \mathrm{MT}$ of HEU per month, limited by the capacity of the USF evaporator.

- The $\mathrm{HE} \mathrm{UO}_{3}$ is packaged in sealed containers for shipment back to 247-F.

- The $\mathrm{HE} \mathrm{UO}_{3}$ is blended with depleted $\mathrm{UO}_{3}$ in the 247-F Facility, then packaged in sealed drums for accountability, stored, then transported to the storage site or to a fuel fabricator.

The costs for 221-H would be similar to Option 5 above, with the addition of new blender equipment in $247-\mathrm{F}$, put at $\$ 2$ million. The effective $\$ / \mathrm{kg}$ HEU cost must be modified to reflect the higher effective HEU throughput of HE $\mathrm{UO}_{3}$ from USF. The annual operating costs for $247-\mathrm{F}$ must also be increased to reflect the added function of powder blending, put at $\$ 5$ million. The cost estimates are then as shown in Table 20. 
Table 20. Summary of Costs Associated with Option 6

\begin{tabular}{|l|r|}
\hline Capital costs (\$ million) & 26.6 \\
247-F & 7.0 \\
221-H & 19.5 \\
Safety and environmental studies costs (\$ million) & 6.5 \\
$247-F$ & 2.0 \\
221-H & 4.5 \\
Total capital and preparation costs (\$ million) & 33.1 \\
\hline Surveillance and maintenance costs (\$ million) & 37.0 \\
247-F & 1.0 \\
221-H & 36.0 \\
Annual operating costs above S\&M (\$ million) & 37.0 \\
247-F & 16.0 \\
221-H & 21.0 \\
& 74.0 \\
\hline
\end{tabular}

The estimate of present worth (see Table 21) and resulting S/kg HEU are given, assuming $12 \mathrm{MT} / \mathrm{yr}, 240 \mathrm{MT}$ HEU equivalent total processed over 12 years. The costs are improved over Options 5 and 6 above, but still fail to provide for conversion of $500 \mathrm{MT}$ HEU.

Table 21. Present Worth for Option 6, $n=20$ yrs

\begin{tabular}{|c|l|l|}
\hline Interest rate & PW, S M & S/kg HEU* \\
$10 \%$ & 663 & 4144 \\
$9 \%$ & 709 & 4429 \\
$8 \%$ & 760 & 4748 \\
$7 \%$ & 817 & 5107 \\
$6 \%$ & 882 & 5512 \\
$5 \%$ & 955 & 5971 \\
\hline
\end{tabular}

* - The capacity of the USF is estimated at $8 \mathrm{MT}$ oxide/yr, or $160 \mathrm{MT}$ total HEU equivalent over 20 years. 


\section{Option 7. 321-M Making LEU Metal; 221F, FA Line Converting to UO 3 Powder}

This option would melt and blend metal in $321-\mathrm{M}$, and then provide LEU metal to 221-F. The only justification for this option would be if both these conditions were true:
a. the HEU and/or DU feedstocks had impurities requiring extraction
b. F Canyon could not handle HEU dissolution directly.

The availability of adequate supplies of depleted $\mathrm{UO}_{3}$ powder at SRS makes condition a. unlikely, and option 2 above indicates that F Canyon can be modified to directly accept HEU for dissolution. Discussions with 221-F technical representatives indicate that the handling of LEU (5 wit\% U.235) would reduce, but not eliminate, criticality concems compared to those in Option 2, and full safety studies for the dissolvers and FA Line would still be required. As a result, the costs associated with this option would then combine those of 247-F for storage, and costs of $321-\mathrm{M}$ and $221-\mathrm{F}$ outlined above. Shipping containers would still be required in $321-\mathrm{M}$, for storage and shipping to 221-F.

The economics are not be expected to compare favorably with the target cost of LEU. However for completeness, the costs associated with this option are summarized in Table 22. 
Table 22. Summary of Costs Associated with Option 7

\begin{tabular}{|c|c|}
\hline Capital costs ( $\$$ million) & 50.7 \\
\hline $247-F$ & 5.0 \\
\hline $321 \cdot M$ & 18.7 \\
\hline $221 \cdot \mathrm{F}$ & 27.0 \\
\hline Safety and environmental studies costs (S million) & 9.5 \\
\hline $247-\mathrm{F}$ & 2.0 \\
\hline $321-M$ & 2.5 \\
\hline $221 \cdot \mathrm{F}$ & 5.0 \\
\hline Total capital and preparation costs ( $\$$ million) & 60.2 \\
\hline Surveillance and maintenance costs ( $\$$ million) & 38.5 \\
\hline $247 \cdot \mathrm{F}$ & 1.0 \\
\hline $321 \cdot M$ & 1.5 \\
\hline $221 \cdot \mathrm{F}$ & 36.0 \\
\hline Annual operating costs above S\&M ( $\$$ million) & 51.0 \\
\hline $247 . \mathrm{F}$ & 11.0 \\
\hline $321 \cdot \mathrm{M}$ & 19.0 \\
\hline $221 \cdot \mathrm{F}$ & 21.0 \\
\hline Total annual operating costs ( $\$$ million) & 89.5 \\
\hline
\end{tabular}

The estimate of present worth (see Table 23) and resulting \$/kg HEU are given, assuming $500,000 \mathrm{~kg}$ of HEU. The economics of this option still compare favorably to the target cost of $\$ 1.5 \times 10^{4} / \mathrm{kg}$ for conversion of 500 MT HEU, but exceed that of the previous options as it required operation of three major SRS facilities.

Table 23. Present Worth for Option 7, $\mathrm{n}=20$ yrs

\begin{tabular}{|c|l|l|}
\hline Interest rate & PW, S million & S/kg HEU \\
$10 \%$ & 822 & 1644 \\
$9 \%$ & 877 & 1754 \\
$8 \%$ & 939 & 1878 \\
$7 \%$ & 1008 & 2017 \\
$6 \%$ & 1087 & 2174 \\
$5 \%$ & 1176 & 2351 \\
\hline
\end{tabular}




\section{Option 8. 321-M Making LEU Metal; 221-H, USF Converting to $\mathrm{UO}_{3}$ Powder}

This is the H-Canyon equivalent to Option 7 for F Canyon. Again, the HEU metal would be blended with DU in $321-\mathrm{M}$, and the resulting LEU metal would be shipped to $\mathrm{H}$ Canyon for dissolution and purification. The Uranium Solidification Facility (USF) would then be used to produce $\mathrm{UO}_{3}$ power.

As with Option 3 for F Canyon, this option for $\mathrm{H}$ Canyon makes sense only under the following conditions:

a. The HEU and/or DU feedstocks had impurities requiring extraction, and

b. H-Canyon could not bandle HEU dissolution directly.

The use of the USF in $\mathrm{H}$ Canyon for conversion of uranyl nitrate to $\mathrm{UO}_{3}$ power still has the throughput constraints discussed under Options 5 and 6 above.

This option will also require the operation of 247-F, 321-M, and 221- $\mathrm{H}$, with resulting impact on the relative economics. The cost estimates are provided in Table 24 for completeness. 
Table 24. Summary of Costs Associated with Option 8

\begin{tabular}{|c|r|}
\hline Capital costs (S million) & 43.2 \\
$247 . F$ & 5.0 \\
$321-M$ & 18.7 \\
$221-H$ & 19.5 \\
Safety and environmental studies costs (S million) & 9.0 \\
247-F & 2.0 \\
321-M & 2.5 \\
221-H & 4.5 \\
Total capital and preparation costs (\$ million) & 52.2 \\
\hline Surveillance and maintenance costs (\$ million) & 38.5 \\
247-F & 1.0 \\
321-M & 1.5 \\
221-H & 36.0 \\
Annual operating costs above S\&M (S million) & 51.0 \\
247-F & 11.0 \\
321-M & 19.0 \\
221-H & 21.0 \\
& 89.5 \\
\hline
\end{tabular}

The estimate of present worth (see Table 25) and resulting $5 / \mathrm{kg}$ HEU are given, again assuming $12.9 \mathrm{MT}$ of HEU equivalent processed over 20 years. As expected, this low throughput makes the effective \$/kg HEU cost highly non-competitive with the target cost of $\$ 1.5 \times 10^{4} / \mathrm{kg}$ for conversion of 500 MT HEU.

Table 25. Present Worth for Option 8, $n=20$ yrs

\begin{tabular}{|c|l|l|}
\hline Interest rate & PW, S million & S/kg HEU* \\
$10 \%$ & 814 & 23396 \\
$9 \%$ & 869 & 24977 \\
$8 \%$ & 931 & 26751 \\
$7 \%$ & 1000 & 28746 \\
$6 \%$ & 1079 & 30999 \\
$5 \%$ & 1168 & 33551 \\
\hline
\end{tabular}

* The capacity of the USF limits processing to $-12.9 \mathrm{MT}$ total HEU equivalent over 20 years. 


\section{Comparative Assessment of Most Likely Options}

The eight options presented above were assessed with respect to implementation cost and expected processing rate. These assessments are summarized bere, along with a discussion of other intangible issues which might impact facility operation.

Option 1, using 321-M for melting of HEU metal and DU to product LEU metal ingots, is attractive for its relative ease of implementation. It involves less handling of material and shorter processing time because of relatively high processing rates. This translates into lower estimated operating cost and risk than the other options. This option also utilizes facilities that are in relatively good condition but have no other intended function in the site's current plans. The resulting LEU metal ingots are stable over a number of years "as is", and if sealed in a canister with dry, inert gas would be stable for many decades. And, subsequent storage costs will be lower because the metal occupies less space.

However, the use of 321-M has a number of drawbacks not fully quantified in this report. First, the $321-\mathrm{M}$ facility is located adjacent to the site administrative area and relatively close to the site boundary. The preference is to locate future processing missions in the center of the site, providing an improved environmental and security buffer.

Also, supplies of purified DU metal are insufficient to convert the assumed $500 \mathrm{MT}$ of HEU. On the order of $10,000 \mathrm{MT}$ of DU metal is required to reduce $500 \mathrm{MT}$ HEU $10-5$ wt\% U-235, and 13,500 MT of DU to blend down to 3.5\% U-235. With the SRS inventory put at $-2,600 \mathrm{MT}$ and the identified DOE complex inventory put at $-4,500 \mathrm{MT}$, additional DU metal would have to be acquired. The DU metal in the DOE stockpile also appears to bave alloying impurities which can not be removed in the melting and blending

cess. A full analysis of the impurities must be performed if the potential lcts for use in commercial fuel are to be assessed. High impurity content - J eliminate certain DU metal from use in the blending process, requiring a targer acquisition of pure DU metal (i.e., from conversion of DU trioxide stored at SRS or UF6 stored at Oak Ridge). Higb impurity content could also impose an economic penalty on the commercial value of the resulting ingots. If the DOE objective is to use existing stockpiles of DU metal regardless of impurity content, this may dictate dissolution and chemical extraction to maintain any commercial value of the final product. This would effectively eliminate the 321-M melting option. Finally, note that the metal form is not the preferred form for input to commercial fuel fabrication facilities.

Option 2, dissolution of the HEU metal in F Canyon and processing to a final $\mathrm{UO}_{3}$ powder form in FA Line, has several advantages. The canyon option offers the flexibility for dissolution and blending with any DU input stock. including metal or oxides. The solvent extraction will also remove any impurities. However, the preferred action at SRS would be to utilize existing site inventories of high purity depleted uranium tri-oxide powder, these being sufficient to convert the entire $500 \mathrm{MT} \mathrm{HEU}$. In any event, the extraction cycle would be used to tailor solution chemistry for input to FA Line. Denitrating in FA Line then can produce a low enriched uranium tri-oxide 
powder, thought to be better suited than metal for input to commercial fuel fabrication.

The remaining attractive option (option 3) is production of LE uranyl nitrate solution after prosessing through $\mathrm{F}$ or $\mathrm{H}$ Canyon. In this case, $\mathrm{H}$ Canyon may actually be preferred, given its history of processing highly enriched uranium fuels. A commercial shipper would then take receipt of the uranyl nitrate at the canyons, loading the solution into approved shipping containers for transport offsite. The costs are judged to be slightly lower, bypassing as it does any final denitrating step.

Table 26 summarizes the attributes, costs, and resulting estimates of present worth and effective $\$ / \mathbf{k g}_{\mathrm{g}}$ HEU processing cost for all the options in this report. Table 27 presents a chart of the facilities which combine to make up the eight options presented bere.

Table 26. Quantitative Attributes for HIEU Blend Down Options at SRS

\begin{tabular}{|c|c|c|c|c|c|c|c|c|}
\hline Process Option & $\begin{array}{l}\text { A. } \\
\text { LEU } \\
\text { Product } \\
\text { Form } \\
\end{array}$ & $\begin{array}{l}\text { B. } \\
\text { MT }\end{array}$ & $\begin{array}{l}\text { C. } \\
\text { Capital } \\
\text { SM } \\
\end{array}$ & $\begin{array}{l}\text { D. } \\
\text { S\&E } \\
\text { SM } \\
\end{array}$ & $\begin{array}{l}\text { E. } \\
\text { S\&M } \\
\text { SM/yr }\end{array}$ & $\begin{array}{l}\text { F. } \\
\text { Oper. } \\
\text { SM/yr }\end{array}$ & $\begin{array}{l}\text { G. } \\
\text { PW } \\
\text { SM } \\
\end{array}$ & $\begin{array}{l}\mathrm{H} . \\
\text { S/kg }\end{array}$ \\
\hline 1. $321-\mathrm{M}$ & Metal & 500 & 23.7 & 4.5 & 2.5 & 30.0 & 373 & 7.45 \\
\hline 2. 221-F, FA Line & $\mathrm{UO}_{3}$ & 500 & 32.0 & 7.0 & 37.0 & 32.0 & 770 & 1,540 \\
\hline 3. $221-\mathrm{F}$ or $221-\mathrm{H}$ & $\begin{array}{l}\text { Uranyl } \\
\text { Nituate } \\
\text { Sol }\end{array}$ & 500 & 24.5 & 8.5 & 37.0 & 25.0 & 690 & 1,380 \\
\hline 4. $221-\mathrm{H}$, Sol. to FA Line & $\mathrm{UO}_{3}$ & 500 & 32.0 & 13.0 & 37.0 & 32.0 & 776 & 1,552 \\
\hline 5. $221-\mathrm{H}$, USF & $\mathrm{UO}_{3}$ & 34.8 & 24.5 & 6.5 & 37.0 & 32.0 & 762 & 21,896 \\
\hline $\begin{array}{l}\text { 6. } 221-\mathrm{H}, \mathrm{HE} \mathrm{UO} 3 \\
\text { to } 247-\mathrm{F}\end{array}$ & $\mathrm{UO}_{3}$ & 160 & 26.6 & 6.5 & 37.0 & 37.0 & 817 & 5,107 \\
\hline $\begin{array}{l}\text { 7. } 321-\mathrm{M} \text {, LEU to } 221-\mathrm{F} \text {, } \\
\text { FA Line }\end{array}$ & $\mathrm{UO}_{3}$ & 500 & 50.7 & 9.5 & 38.5 & 51.0 & 1,008 & 2,017 \\
\hline $\begin{array}{l}\text { 8. 321-M,LEU to 221-H, } \\
\text { USF }\end{array}$ & $\mathrm{UO}_{3}$ & 34.8 & 43.2 & 9.0 & 38.5 & 51.0 & 1,000 & 28,746 \\
\hline
\end{tabular}

1. The HEU metal is melted in 321-M vacuum furnaces, and blended with DU metal. This is relatively easy to implement. However, purified DU metal supplies are insufficient to convert the entire $500 \mathrm{MT}$ HEU inventory. The metal product is judged least desirable for input into a commercial fuel fabrication process. The $321-\mathrm{M}$ facility is also unfavorably located near the site perimeter and its administrative area.

2. The HEU metal is dissolved in F Canyon and blended with DU feedstock (metal or UO3 powder), producing LE uranyl nitrate solution. This solution is passed through the second uranium extraction cycle and sent to FA Line for denitrating to a $\mathrm{LE} \mathrm{UO} 3$ powder. Canyon operating costs are high relative io 321-M; however, the final product is judged more acceptable for input to a commercial fuel. 
Table 26, Continued.

fabrication prncess. SRS also has sufficient quantity of high purity $\mathrm{UO}_{3}$ powder on hand to convert the entire 500 MT of HEU.

3. The HEU metal is dissolved in 221-F and blended with $\mathrm{DU}$ feedstock (metal or $\mathrm{UO}_{3}$ powder), producing LE uranyl nitrate solution, which is passed through the second uranium extraction cycle. In 221-H, the metal is dissolved and a HE uranyl nitrate solution is passed through the second uranium extraction cycle. Blending with depleted uranyl nitrate solution occurs outside 221-H in the USF storage tank. In both cased the product is in the form of uranyl nitrate solution, which would be loaded into licensed tank trucks and shipped offsite to a commercial fuel fabrication facility. This is estimated to be slightly cheaper than full operation of F Canyon and FA Line. Shipment of uranyl nitrate solution would require DOE approval.

4. H Canyon is used for dissolution of HEU metal to HE uranyl nitrate solution. Blending with depleted uranyl nitrate solution occurs outside 221-H $\mathrm{n}$ the USF storage tank. The solution is sent to FA Line for conversion to $\mathrm{UO}_{3}$ powder. This option requires $D O E$ approval for shipment of $L E$ solutions.

5. This option is similar to option 2, using 221-H and the Uranium Solidification Facility (USF). The capacity of USF is insufficient to convert the entire inventory to $\mathrm{UO}_{3}$ powder in 20 years. This concept is thus not viable, but is included for completeness.

6. H Canyon dissolves the HEU metal, but does not blend down. The USF then produces HEU UO 3 powder, which is sent to 247-F for mechanical blending with DU UO 3 powder. At 1 MT/mo, the USF could produce $>200 \mathrm{MT}$ HE UO 3 powder over a 20-year campaign. Lower U-235 content in the USF powder will reduce the effective HEU blend-down rate proportionally.

7. This combines options 1 and 2 above. 321-M is used to pre-blend the HEU to a LEU metal product. which is then sent to F Canyon. This option makes sense only if F Canyon is not capable of handing HEU (not thought to be the case), and a metal product is not acceptable. The costs are higher, requiring as it does the operation of both $321-\mathrm{M}$ and $221-\mathrm{F}$.

8. This option is similar to option 3, with 321-M providing LEU metal 221-H and USF. H Canyon is fully capable of handling HEU, so this is included only for completeness. USF still has insufficient capacity, processing an estimated $34.8 \mathrm{MT}$ of HEU over $2 \theta$ years, making $670 \mathrm{MT}$ of LE oxide powder.

Key:

A. Final form of the LEU product from SRS. Either metal, $\mathrm{UO}_{3}$ powder, or uranyl nitrate solution.

B. HEU throughput over a 20-year campaign, up to the assumed 500 MT HEU.

C. Estimate of one-time capital equipment and facility costs.

D. Estimate of one-time safety and environmental costs for study and documentation.

E. Assumed baseline cost for surveillance and maintenance of facility in first year of tumover to Environmental Restoration.

F. Annual operating costs above those required for S\&M under the ER program.

G. Present worth of option, based on capital and annual operating expenses over a 20-year period. with annual interest at $7 \%$. Range for $0.1 \leq i \leq 0.5$ given in report.

H. Net cost of processing on a per $\mathrm{kg}$ HEU basis $=($ column $\mathrm{G}) /($ column $B)$. 
powder, thought to be better suited than metal for input to commercial fuel fabrication.

The remaining attractive option (option 3 ) is production of LE uranyl nitrate solution after processing through $\mathrm{F}$ or $\mathrm{H}$ Canyon. In this case, $\mathrm{H}$ Canyon may actually be preferred, given its history of processing highly enriched uranium fuels. A commercial shipper would then take receipt of the uranyl nitrate at the canyons, loading the solution into approved shipping containers for transport offsite. The costs are judged to be slightly lower, bypassing as it does any final denitrating step.

Table 26 summarizes the attributes, costs, and resulting estimates of present worth and effective $\mathbf{S / k g}$ HFU processing cost for all the options in this report. Table 27 presents a chan of the facilities which combine to make up the eight options presented bere.

Table 26. Quantitative Attributes for HEU Blend Down Options at SRS

\begin{tabular}{|c|c|c|c|c|c|c|c|c|}
\hline Process Option & $\begin{array}{l}\text { A. } \\
\text { LEU } \\
\text { Product } \\
\text { Form }\end{array}$ & $\begin{array}{l}\text { B. } \\
\text { MT }\end{array}$ & $\begin{array}{l}\text { C. } \\
\text { Capital } \\
\text { SM }\end{array}$ & $\begin{array}{l}\text { D. } \\
\text { S\&E } \\
\text { SM }\end{array}$ & $\begin{array}{l}\text { E. } \\
\text { S\&M } \\
\text { S M/Yr }\end{array}$ & $\begin{array}{l}\text { F. } \\
\text { Oper. } \\
\text { SM/yr }\end{array}$ & $\begin{array}{l}\text { G. } \\
\text { PW } \\
\text { SM }\end{array}$ & H. \\
\hline 1. $321-\mathrm{M}$ & Metal & 500 & 23.7 & 4.5 & 2.5 & 30.0 & 373 & 745 \\
\hline 2. 221-F, FA Line & $\mathrm{UO}_{3}$ & 500 & 32.0 & 7.0 & 37.0 & 32.0 & 770 & 1.540 \\
\hline 3. $221-\mathrm{F}$ or $221-\mathrm{H}$ & $\begin{array}{l}\text { Uranyl } \\
\text { Nitraie } \\
\text { Sol }\end{array}$ & 500 & 24.5 & 8.5 & 37.0 & 25.0 & 690 & 1,380 \\
\hline 4. 221-H, Sol. to FA Line & $\mathrm{UO}_{3}$ & 500 & 32.0 & 13.0 & 37.0 & 32.0 & 776 & 1.552 \\
\hline 5. $221-\mathrm{H}$, USF & $\mathrm{UO}_{3}$ & 34.8 & 24.5 & 6.5 & 37.0 & 32.0 & 762 & 21,896 \\
\hline $\begin{array}{l}\text { 6. 221- } \mathrm{H}, \mathrm{HE} \mathrm{UO} 3 \\
\text { to } 247-\mathrm{F}\end{array}$ & $\mathrm{UO}_{3}$ & 160 & 26.6 & 6.5 & 37.0 & 37.0 & 817 & 5,107 \\
\hline $\begin{array}{l}\text { 7. } 321-\mathrm{M}, \text { LEU to } 221-\mathrm{F} \text {, } \\
\text { FA Line }\end{array}$ & $\mathrm{UO}_{3}$ & 500 & 50.7 & 9.5 & 38.5 & 51.0 & 1,008 & 2,017 \\
\hline $\begin{array}{l}\text { 8. 321-M,LEU to 221-H, } \\
\text { USF }\end{array}$ & $\mathrm{UO}_{3}$ & 34.8 & 43.2 & 9.0 & 38.5 & 51.0 & 1,000 & 28,746 \\
\hline
\end{tabular}

Description:

1. The HEU metal is melted in 321-M vacuum furnaces, and blended with DU metal. This is relatively easy to implement. However, purified DU metal supplies are insufficient to convert the entire $500 \mathrm{MT}$ HEU inventory. The metal product is judged least desirable for input into a commercial fuel fabrication process. The 321-M facility is also unfavorably located near the site perimeter and its administrative area.

2. The HEU metal is dissolved in $\mathrm{F}$ Canyon and blended with $\mathrm{DU}$ feedstock (metal or $\mathrm{UO}_{3}$ powder), producing LE uranyl nitrate solution. This solution is passed through the second uranium extraction cycle and sent to FA Line for denitrating to a $\mathrm{LE} \mathrm{UO} 3$ powder. Canyon operating costs are high relative to 321-M; bowever, the final product is judged more acceptable for input to a commercial fuel. 


\section{Table 26, Continued.}

fabrication process. SRS also has sufficient quantity of high purity $\mathrm{UO}_{3}$ powder on hand to convert the entire $500 \mathrm{MT}$ of HEU.

3. The HEU metal is dissolved in 221-F and blended with $\mathrm{DU}$ feedstock (metal or $\mathrm{UO}_{3}$ powder), producing LE uranyl nitrate solution, which is passed through the second uranium extraction cycle. In 221. $\mathrm{H}$, the metal is dissolved and a HE uranyl nitrate solution is passed through the second uranium extraction cycle. Blending with depleted uranyl nitrate solution occurs outside 221-H in the USF storage tank. In both cased the product is in the form of uranyl nitrate solution, which would be loaded into licensed tank trucks and shipped offsite to a commercial fuel fabrication facility. This is estimated to be slighuly cheaper than full operation of F Canyon and FA Line. Shipment of uranyl nitrate solution would require DOE approval.

4. H Canyon is used for dissolution of HEU metal to HE uranyl nitrate solution. Blending with depleted uranyl nitrate solution occurs outside $221-\mathrm{H}$ a the USF storage tank. The solution is sent to FA Line for conversion to $\mathrm{UO}_{3}$ powder. This option requires $\mathrm{DOE}$ approval for shipment of $\mathrm{LE}$ solutions.

5. This option is similar to option 2, using $221-\mathrm{H}$ and the Uranium Solidification Facility (USF). The capacity of USF is insufficient to convert the entire inventory to $\mathrm{UO}_{3}$ powder in 20 years. This concept is thus not viable, but is included for completeness.

6. H Canyon dissolves the HEU metal, but does not blend down. The USF then produces HEU UO powder, which is sent to 247-F for mechanical blending with DU UO 3 powder. At $1 \mathrm{MT} / \mathrm{mo}$, the USF could produce $>200 \mathrm{MT}$ HE UO 3 powder over a 20-year campaign. Lower U-235 content in the USF powder will reduce the effective HEU blend-down rate proportionally.

7. This combines options 1 and 2 above. 321-M is used to pre-blend the HEU to a LEU metal product, which is then sent to F Canyon. This option makes sense only if F Canyon is not capable of handling HEU (not thought to be the case), and a metal product is not acceptable. The costs are higher, requiring as it does the operation of bolh 321-M and 221-F.

8. This option is similar to option 3, with 321-M providing LEU metal 221-H and USF. H Canyon is fully capable of handling HEU, so this is included only for completeness. USF still has insufficient capacity, processing an estimated $34.8 \mathrm{MT}$ of HEU over 20 years, making $670 \mathrm{MT}$ of LE oxide powder.

Key:

A. Final form of the LEU product from SRS. Either metal, $\mathrm{UO}_{3}$ powder, or uranyl nitrate solution.

B. HEU throughput over a 20-year campaign, up to the assumed 500 MT HEU.

C. Estimate of one-time capital equipment and facility costs.

D. Estimate of one-time safety and environmental costs for study and documentation.

E. Assumed baseline cost for surveillance and maintenance of facility in first year of tumover to Environmental Restoration.

F. Annual operating costs above those required for S\&M under the ER program.

G. Present worth of option, based on capital and annual operating expenses over a 20-year period, with annual interest at $7 \%$. Range for $0.1 \leq$ i 50.5 given in report.

H. Net cost of processing on a per kg HEU basis = (column G) / (column B). 
Table 27. Facillty Use for EEU Blend Down Processing Options at SRS

\begin{tabular}{|c|c|c|c|c|c|c|c|c|}
\hline & \multicolumn{8}{|c|}{ Options } \\
\hline & 1 & 2 & 3 & 4 & 5 & 6 & 7 & 8 \\
\hline \multicolumn{9}{|l|}{ 247-F } \\
\hline Storage of HEU & $x$ & $x$ & $x$ & $x$ & $x$ & $x$ & $x$ & $x$ \\
\hline Blending of $\mathrm{HUUO}_{3}$ to $\mathrm{LEUO}_{3}$ & & & & & $\mathbf{x}$ & & & \\
\hline \multicolumn{9}{|l|}{$321-\mathrm{M}$} \\
\hline Melt and Blend HEU to LEU metal & $x$ & & & & & & $\mathbf{x}$ & $\mathbf{x}$ \\
\hline \multicolumn{9}{|l|}{$221 \cdot F$} \\
\hline Dissolve & & & & & & & $\mathbf{x}$ & \\
\hline Dissolve and blend & & $x$ & $x$ & & & & & \\
\hline Extraction & & $x$ & $x$ & & & & $\mathbf{x}$ & \\
\hline Denitrate in FA Line & & $\mathbf{x}$ & & $x$ & & & $\mathbf{x}$ & \\
\hline \multicolumn{9}{|l|}{ 221-H } \\
\hline Dissolve & & & & & $x$ & $x$ & & $\mathbf{x}$ \\
\hline Dissolve and blend & & & $x$ & $\mathbf{x}$ & & & & \\
\hline Extraction & & & $\mathbf{x}$ & $\mathbf{x}$ & $x$ & $x$ & & $x$ \\
\hline USF storage tank & & & & $\mathbf{x}$ & $x$ & & $x$ & \\
\hline USF denitrate & & & & & $x$ & $\mathbf{x}$ & & $x$ \\
\hline
\end{tabular}




\section{References}

1. Facsimile transmission, 11/25/92, Bill Newton to Chuck Mason, of a 11/06/92 letter from Philip G. Sewell, Deputy Assistant Secretary for Uranium Enrichment, Office of Nuclear Energy, on blending of highly enriched uranium.

2. J.M. McKibben to M.F. Sujka, T.H. Gould, Task Force Report on SRS Facilities That May Be Used To Blend Down HEU, WSRC-RP-921365 (U), December 4, 1992.

3. Nuclear Fuel, page 4, Vol. 18, No. 5, March 1, 1993.

4. Nuclear Fuel, page 1, Vol. 18, No. 10, May 10, 1993.

5. Nuclear Fuel, page 1, Vol. 18, No. 11, May 24, 1993.

6. J.J. Steyn, Weapons Material and the Commercial Fuel Cycle, Transactions of the American Nuclear Society, Volume 68, Part A, June 20, 1993

7. Nuclear Fuel, page 1, Vol. 18, No. 6, March 15, 1993.

8 DPST-SA-200-16, Safety Analysis Report, 247-F Facility, August 1985.

9. DOE Order 6430.1A, General Design Criteria, Division 13, Special Facilities, Part 1305, Plutonium Storage Facilities, April 6, 1989.

10. Gedes, R.L., and D.L. McWhorter to D.F. Chostner, Capital and Operating Cost Estimate for the Proposed Highly Enriched Uranium Blending Program (U), NMP-PLS-93-0012, January 22, 1993, Westinghouse Savannah River Company, Aiken, SC 29801

11. M.L. Hyder et al., Processing of Itradiated Enriched Uranium Fuels at the Savannah River Plant, DP-1500, April 1979, Savannah River Site, Aiken, SC 29801.

12. Chostner, D.F. to J.M. McKibben, Blending High Enriched Uranium In F-Canyon (U), NMP-SEL-93-0010, January 25, 1993, Westinghouse Savannah River Company, Aiken, SC 29801.

13. Savannah River Site Five Year Plan (U), (FY 1995 Budget Year), Materials Production, WSRC-RP-93-673, May 1993, Westinghouse Savannah River Company, Aiken, SC 29801.

14. Rhode, F.C. to W.E. Bickford, Private communication, August 17, 1993. Westinghouse Savannah River Company, Aiken, SC 29801.

15. American Society for Testing and Materials (ASTM), C-996, Standard Specification for Uranium Hexafluoride Enriched to Less Than $5 \%$ U.235.

16. WcWhorter, D.L., Nuclear Materials Processing Division SRS Depleted Uranium Trioxide Transition Plan (U), NMP-PLS-93-0013, WSRC. January 28, 1993.

17. American Society for Testing and Materials (ASTM), C.753, Standard Specification for Nuclear Grade Sinterable Uranium Dioxide Powder.

18. American Society for Testing and Materials (ASTM), C-788, Standard Specification for Nuclear Grade Uranyl Nitrate Solutions.

19. ANSI/ANS 8.1-1983. "Subcritical Limits for Uniform Aqeous Solutions of Low-Enriched Uranium", Table 6, page 9. 


\section{APPENDIX A}

\section{URANIUM MASS BALANCES AND MARKET VALUE}

This appendix derives the equations for mass balance of $U .235$ during blending. As an estimate of commercial value, the comparable mass balance is derived for enrichment of U-235 from natural uranium. The relationships for separative work units (SWU) and materials feeds are also provided. Representative spot market prices are then used to derive an estimate of the commercial value of the blended material, if it were to be provided instead by conventional enrichment services. The results are summarized in Table A.1 below.

Table A.1 Summary of Material Balances and Estimated Value of Blended HEU

\begin{tabular}{|c|c|c|c|c|c|c|c|c|}
\hline $\begin{array}{l}\text { U.235 } \\
\text { enrich- } \\
\text { ment }\end{array}$ & $\begin{array}{l}\mathrm{kg} \text { of } \\
\text { feed } \\
\text { per } \mathrm{ke} \\
\text { prod }\end{array}$ & $\begin{array}{l}\mathrm{U}_{3} \mathrm{O}_{8} \\
\text { feed } \\
\text { S/kg }\end{array}$ & $\begin{array}{l}\mathrm{U}_{3} \mathrm{O}_{8} \\
\mathrm{to} \\
\mathrm{UF} \\
\mathrm{S} / \mathrm{kg}_{6}\end{array}$ & SWU & $\begin{array}{l}\text { Cost } \\
\text { S per } \\
\text { swU }\end{array}$ & $\begin{array}{l}\text { Value } \\
\$ \text { p per } \\
\text { kg } \\
\text { prod }\end{array}$ & $\begin{array}{l}\text { kg } \\
\text { prod } \\
\text { per kg } \\
\text { per kg } \\
\text { HEU }\end{array}$ & $\begin{array}{l}\text { ValueS } \\
\text { per kg } \\
\text { HEU }\end{array}$ \\
\hline $3.5 \%$ & 6.46 & 22 & 10 & & 60 & & 28.12 & $1.5 \times 10^{4}$ \\
\hline $5.0 \%$ & 9.39 & 22 & 10 & 8.85 & 60 & 831 & 19.33 & $1.6 \times 10^{4}$ \\
\hline
\end{tabular}

The analytical relationships used to derive the information presented in Table A.1 are fully developed in the text below.

\section{Mass Balance Relationships}

The following variables will be used to designate the HEU uranium input, the diluent. and the product:

$$
\begin{aligned}
& M_{h}=\text { the mass of input HEU, } \\
& M_{d}=\text { the mass of diluent uranium, either DU or } N U \text {, and } \\
& M_{p}=\text { the mass of product uranium. }
\end{aligned}
$$

Further, let:

$x_{h}=$ the fraction of U-235 isotope in the input HEU,

$x_{d}=$ the fraction of U.235 isotope in the diluent DU or NU, and

$x_{p}=$ the fraction of $U-235$ isotope in the product.

The final product enrichment of $x_{p}$, is then expressed as:

$$
x_{p}=\left[x_{h} \times M_{b}+x_{d} \times M_{d}\right] / M_{p}
$$

or

$$
x_{p}=\left[x_{h} \times M_{h}+x_{d} \times M_{d}\right] /\left[M_{h}+M_{d}\right] .
$$

Solving for $M_{d}$ then gives: 
$M_{d}=M_{h} \times\left[x_{b}-x_{p}\right] /\left[x_{p}-x_{d}\right]$.

(3)

The blending of every kilogram of HEU then requires $\left[x_{b}-x_{p}\right] /\left[x_{p}-x_{d}\right]$ kilograms of diluent, and produces $\left(1+M_{d}\right)$ kilograms of product.

A similar relationship can be derived for fuel produced by enrichment. In this case,

$$
M_{f}=M_{p} \times\left[x_{p}-x_{t}\right] /\left[x_{f}-x_{l}\right],
$$

where

$$
\begin{aligned}
& M_{p}=\text { the mass of product uranium } \\
& M_{f}=\text { the mass of feed uranium, } \\
& x_{p}=\text { the fraction of } U-235 \text { isotope in the product. } \\
& x_{f}=\text { the fraction of U-235 isotope in the feed, and } \\
& x_{t}=\text { the fraction of U-235 isotope in the tails. }
\end{aligned}
$$

\section{Material Quantities}

The relatiouships above will be used to calculate the amount of materials that could be produced by using DU or NU, blending down to $5 \%$ or $3.5 \%$ U-235. The following table will give the $\mathrm{kg}$ of product resulting from the blend down of $1 \mathrm{~kg}$ of HEU, assuming a final enrichment of $3.5 \%$ and $5 \%$ U-235. The U-235 fractional content of DU and NU will be assumed to be 0.002 and 0.00711 , respectively.

Table A.2. Kg of Product Per $\mathrm{Kg}$ HEU Input

\begin{tabular}{|l|c|c|}
\hline & $\begin{array}{c}\text { kg diluent per kg } \\
\text { HEU }\end{array}$ & $\begin{array}{c}\text { kg product per } \\
\text { kg HEU }\end{array}$ \\
\hline $\begin{array}{l}\text { 3.5\% U-235 enriched } \\
\text { product }\end{array}$ & & \\
\hline NU diluent & 32.09 & 33.09 \\
\hline DU diluent & 27.12 & 28.12 \\
\hline delta & 4.97 & 4.97 \\
\hline $\begin{array}{l}\text { 5\% U-235 enriched } \\
\text { product }\end{array}$ & & \\
\hline NU diluent & 20.52 & 21.52 \\
\hline DU diluent & 18.33 & 19.33 \\
\hline delta & 2.19 & 2.19 \\
\hline
\end{tabular}

For a product blended down to $3.5 \%$ U-235, the use of NU versus DU will then produce an additional $-5 \mathrm{~kg}$ of product for every $\mathrm{kg}$ of $\mathrm{HEU}$ converted.

The ultimate goal is to compare the resulting material to LEU produced by enrichment from NU. As a result, the separative work units (SWU) required to produce the product as if it had been generated from natural uranium will also given for the $3.5 \%$ and $5 \%$ U-235 product, assuming a U-235 tails fraction of 0.002 . The definition of $S W U$ is:

$$
\text { SWU/kg product }=\left(\Phi_{p}-\Phi_{f}\right)-\left(x_{p}-x_{f}\right)\left(\Phi_{f}-\Phi_{W}\right) /\left(x_{f}-x_{W}\right) \text {. }
$$


where

$$
\begin{aligned}
& \Phi\left(x_{k}\right)=\left(2 x_{k}-1\right) \ln \left(x_{k} /\left(1-x_{k}\right)\right) \\
& x_{k}=U-235 \text { weight fraction of material } k \text {, } \\
& p=\text { product, (i.e., } 0.035 \text { or } 0.05) \\
& f=\text { feed, (i.e., } 0.00711) \\
& w=\text { tails (i.e., } 0.002)
\end{aligned}
$$

This calculates out to 5.41 SWU/kg of product for $3.5 \%$ U-235 fuel, and 8.85 SWU/kg of product for $5 \%$ U-235 fuel. Table A.3 below then summarizes the $\mathrm{kg}$ of product that will be produced by blending each $\mathrm{kg}$ of HEU for the various options, and also gives the resulting equivalent SWU if this were to be produced by enrichment.

Table A.3. SWU Equivalent for HEU Blend Down

\begin{tabular}{|l|c|c|c|}
\hline \multicolumn{1}{|c|}{ Product } & $\begin{array}{c}\text { SWU per kg } \\
\text { product }\end{array}$ & $\begin{array}{c}\text { kg product per } \\
\text { kg HEU }\end{array}$ & $\begin{array}{c}\text { Equivalent } \\
\text { SWU/kg HEU }\end{array}$ \\
\hline $\begin{array}{l}\text { 3.5\% U-235 Product, } \\
\text { using }\end{array}$ & & & \\
\hline NU diluent & 5.41 & 33.09 & 179 \\
\hline DU diluent & 5.41 & 28.12 & 152 \\
\hline $\begin{array}{l}\text { 5\% U-235 Product } \\
\text { using }\end{array}$ & & & 190 \\
\hline NU diluent & 8.85 & 21.52 & 171 \\
\hline DU diluent & 8.85 & 19.33 & \\
\hline
\end{tabular}

For example, $1 \mathrm{~kg}$ of HEU blended down to $3.5 \%$ U-235 with NU will product $33.09 \mathrm{~kg}$ of product. This would require 179 SWU to produce by enrichment. Blending down with DU will produce $28.12 \mathrm{~kg}$ of product, which would require $152 \mathrm{SWU}$ if produced by enrichment.

If this material were enriched in a gaseous diffusion plant, the material inputs from equation (4) would be $9.39 \mathrm{~kg}$ natural uranium input for every $\mathrm{kg}$ of product enricbed 10 $5 \% \mathrm{U}-235$, and $6.46 \mathrm{~kg}$ natural uranium input for every $\mathrm{kg}$ of product enriched to $3.5 \%$.

\section{Market Value}

The final market value of any material derived from blending down of HEU should be compared to spot market prices for enriched material. Representative prices are shown in Table A.4.

The "value" of commercial material can then be expressed as the cost of inputs to the enrichment process, and cost of SWU:

Value $=($ cost of natural oxide)

$$
\begin{aligned}
& +(\text { cost of conversion to UF6) } \\
& +(\operatorname{cost} \text { of SWU }) .
\end{aligned}
$$


Table A.4. Representative Spot Market Prices for Nuclear Material

\begin{tabular}{|l|l|}
\hline \multicolumn{1}{|c|}{ Commodity } & \multicolumn{1}{c|}{ Spot market price } \\
\hline SWU & $\$ 60 / S W U$ \\
\hline $\mathrm{U}_{3} \mathrm{O}_{8}$ & $\$ 10 / \mathrm{hb}, \$ 22 / \mathrm{kg}_{8}$ \\
\hline $\mathrm{U}_{3} \mathrm{O}_{8}$ to UF6 & $\$ 10 / \mathrm{kg}_{8}$ \\
\hline $\mathrm{UF}_{6}$ to metal & $\$ 10 / \mathrm{kg}_{8}$ \\
\hline
\end{tabular}

On a "per kg of product" besis for 3.5\% material, this works out to:

Value, $3.5 \%=\left(6.46 \mathrm{~kg} \mathrm{U} \mathrm{U}_{3} / \mathrm{kg}_{8}\right.$ product $)\left(522 / \mathrm{kg}_{8} \mathrm{U}_{3} \mathrm{O}_{8}\right)$

$+\left(6.46 \mathrm{~kg} \mathrm{U}_{3} \mathrm{O}_{8} / \mathrm{kg}_{8}\right.$ product)(\$10/kg U3O8 to UF6)

+ (5.41 SWU/kg product)(S60/SWU)

= $\$ 531 / \mathrm{kg}$ product.

For $5 \%$ material, this works out to $\$ 831 / \mathrm{kg}$ of product. This is summarized in Table A.S below. Also shown are the effective \$/kg HEU blended, using the ( $\mathrm{kg}$ product/kg HEU) values from Table A.3 above.

Table A.5. Product Value For Commercial Fuel Feed Stock

\begin{tabular}{|l|l|l|l|}
\hline \multicolumn{1}{|l|}{ Inrichment } & \$Nk product & $\begin{array}{l}\text { kg product per } \\
\text { kg HEU }\end{array}$ & $\begin{array}{l}\text { Erfective \$kg } \\
\text { HEU }\end{array}$ \\
\hline $\begin{array}{l}3.5 \% \text { U-235 product } \\
\text { enrichment }\end{array}$ & & & \\
\hline using NU & 531.32 & 33.09 & $1.76 \times 10^{4}$ \\
\hline using DU & 531.32 & 28.12 & $1.49 \mathrm{E} \times 10^{4}$ \\
\hline delta & 4.97 & $2.64 \times 10^{3}$ & \\
\hline $\begin{array}{l}5 \% \text { U-235 product } \\
\text { enrichment }\end{array}$ & & & \\
\hline using NU & 831.48 & 21.52 & $1.79 \times 10^{4}$ \\
\hline using DU & 831.48 & 19.33 & $1.61 \times 10^{4}$ \\
\hline delta & 2.19 & $1.82 \times 10^{3}$ & \\
\hline
\end{tabular}

The profit from any blend down of HEU is then the difference between value and costs of feed stock, blending, and any final conversion costs (i.e., to $\mathrm{UF}_{6}$ or $\mathrm{UO}_{2}$ :

"Profit" = (commercial value)

- (blend down feed stock costs)

- (blending operations costs)

- (final conversion costs).

For $3.5 \%$ product, each $\mathrm{kg}$ of HEU requires $\sim 5 \mathrm{~kg}$ more feed with NU versus DU which must be purchased, and $-5 \mathrm{~kg}$ more of product which may need conversion to some final 
form for input to a commercial fuel fabrication facility. However, the added costs will be more than off-set by the bigh commctal value of the resulting material.

Recognizing that the blending operation costs will tend to be constant (i.e., the canyon operating costs are roughly the same whether processing 5 tons/yr or 10 tons/yr), then the difference in profit between using NU or DU on a per $\mathrm{kg}$ HEU basis can be expressed as:

Profit delte $=\left[\left(M_{d, n u}+1\right) \cdot\left(M_{d i d u}+1\right)\right](P)$

$$
\begin{aligned}
& -\left[\left(C_{d, n u} M_{d, n u}\right) \cdot\left(C_{d, d u} M_{d, d u}\right)\right] \\
& -\left[C_{b l e n d i n g, ~ n u} \cdot C_{b l e n d i n g, ~ d u}\right] \\
& -\left[\left(M_{d, n u}+1\right)\left(C_{c, n u}\right) \cdot\left(M_{d, d u}+1\right)\left(C_{c, d u}\right)\right]
\end{aligned}
$$

where

$P=$ market worth, S/kg product,

$M_{d, x}=$ mass of diluent $x$ (i.e., $N U$ or DU), kg.

$C_{d, x}=$ cost of diluent $x, 5 / \mathrm{kg}$.

Cblending, $x=\cos t$ of blending for deluent $x, 5 / k_{8}$

$C_{c, x}=$ cost of conversion for deluent $x, S / k g$.

Assuming that ( $\left.C_{b l e n d i n g, ~ n u} \cdot C_{b l e n d i n g, ~ d u}\right)$ and $C_{c, n u}=C_{c, d u}=C_{c}$, then equation (6) reduces to:

$$
\begin{aligned}
\text { Profit delta }= & {\left[\left(M_{d, n u}+1\right) \cdot\left(M_{d, d u}+1\right)\right](P) } \\
& \cdot\left[\left(C_{d, n u} M_{d, n u}\right) \cdot\left(C_{d, d u} M_{d, d u}\right)\right] \\
& \cdot\left[\left(M_{d, n u}+1\right) \cdot\left(M_{d, d u}+1\right)\right]\left(C_{c}\right), \\
= & {\left[\left(M_{d, n u}+1\right) \cdot\left(M_{d, d u}+1\right)\right]\left(P \cdot C_{c}\right) } \\
& \cdot\left[\left(C_{d, n u} M_{d, n u}\right) \cdot\left(C_{d, d u} M_{d, d u}\right)\right]
\end{aligned}
$$

There are likely some costs associated with DU storage, and possible costs for conversion to a form compatible with the processing method chosen. The cost of DU is thus likely to be non-zero. Note bowever that as the cost of $D U$ increases, the profit margin between using NU over DU will increase. Assuming $C_{d, d u}=0$ will thus give the minımum estimate of profit differential. Equation (7) then reduces to:

$$
\begin{gathered}
\text { Minimal profit delta }=\left[\left(M_{d, n u}+1\right) \cdot\left(M_{d, d u}+1\right)\right]\left(P \cdot C_{c}\right) \\
-\left(C_{d, n u} M_{d, n u}\right)
\end{gathered}
$$

For the 3.5\% product, equation (8) takes on the value of:

$$
\text { Minimal profit delta }=4.97\left(\$ 531-C_{C}\right) \cdot(\$ 22 \times 32.09) \text {, }
$$

If the cost of conversion is on the order of $-510 / \mathbf{k g}$, the difference in profit between using NU versus DU for $3.5 \%$ enrichment will then be on the order of $\$ 1.88 \times 10^{3} / \mathrm{kg}$ of HEU processed. 
For the 5\% product, equation (8) takes on the value of:

Minimal Profit Delu $=2.19\left(\$ 831 \cdot C_{C}\right) \cdot(\$ 22 \times 20.52)$.

The difference in profit between using NU versus DU for $5 \%$ U.235 will then be on the order of $11.35 \times 10^{3} \mathrm{hkg}$ of HEU preceseed, with conversion costs at $-\$ 10 / \mathrm{kg}$.

For a cempaign to blend $500 \mathrm{MT}$ of HEU, the difference in profit approaches $\$ 1 \times 10^{\circ}$ and $\$ 6.7 \times 10^{\circ}$ for HEU blended to $3.5 \%$ and $5 \%$ U-235, respectively.

\section{DU Storage Costs}

The 'zero' value assigned above for existing stocks of depleted uranium in the DOE complex may not truly reflect all of the costs and benefits associated with using this material. In fach, the failure to use DU inveatories will imply some on-going costs associawed with storage and maintenance of feclitics. A deferred cost in lerms of storage costs avoided could in fact be asaigned to this material if it were used instead of NU.

If the concept of a deferred cost for use of DU is introduced into equation (7),

$C_{d, d u}$ will take on a negative value. The net effect will be to reduce the profit margin displayed by the use of $N U$ over DU

Equation (7) has been solved for deferred costs ranging from 0 to $-\$ 100 / \mathrm{kg}$, for both the 3.5\% and 5\% U-235 product cases. For each enrichment curves are also shown for cost of final conversion (i.e., to UF6 or UO2) ranging from $\$ 10$ to $\$ 30 / \mathrm{kg}$. 


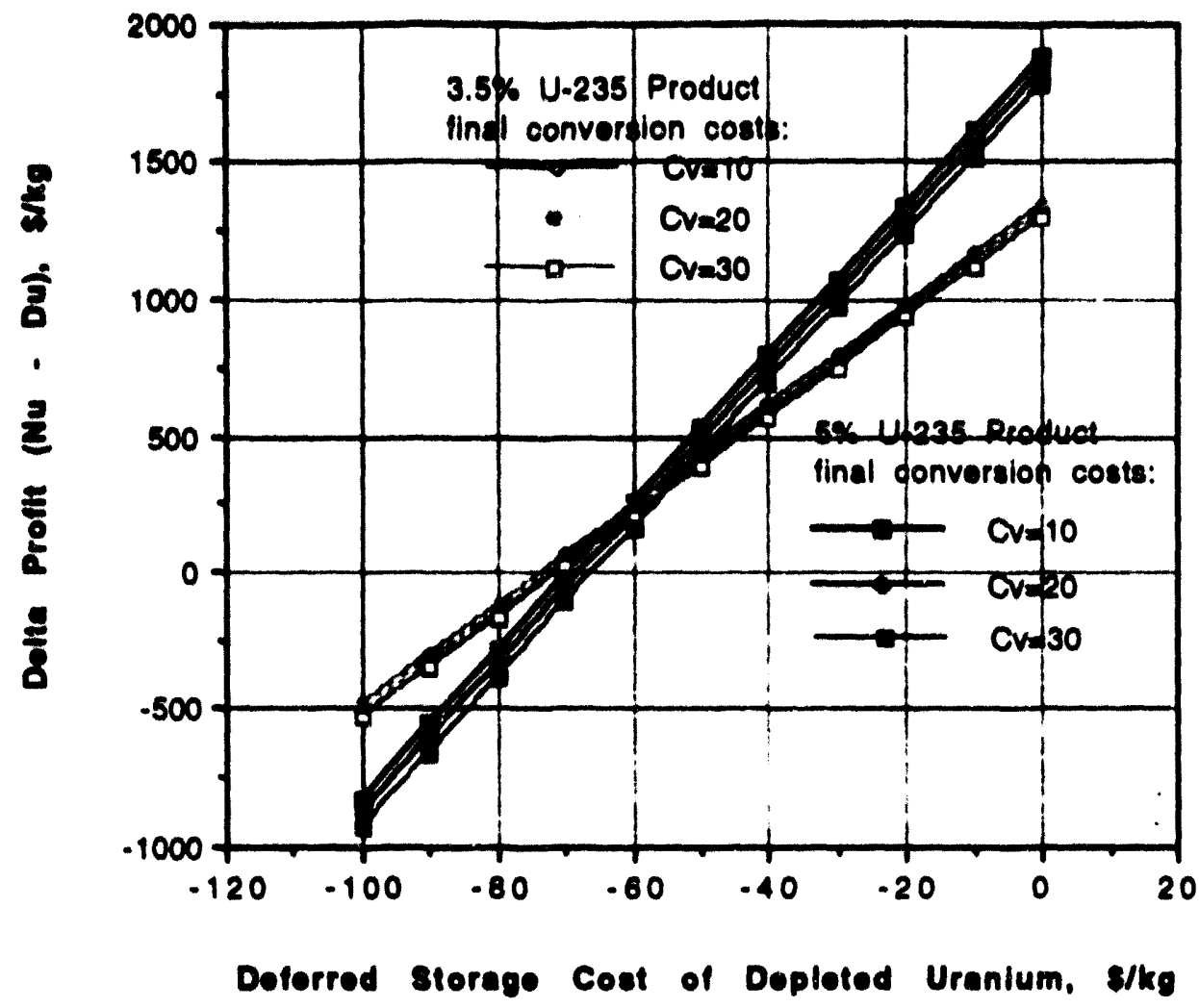

Figure A.1 Pront of Blending HEU With Natural Versus Depleted Uranium, a a Function of DU Storage Costs

Again, the net effect of including a deferred cost for DU is to reduce the margin of profitability for using NU. As can be seen, the profitability of using NU becomes marginal as DU deferred storage costs approach approximately $\$ 67 / \mathrm{kg}$ for the $3.5 \%$ enrichment case, and $-572 / \mathrm{kg}$ for the $5 \%$ enrichment case, or approximately $570 / \mathrm{kg}$ for enrichments in the range of 3.5\% to 5\% U-235. 

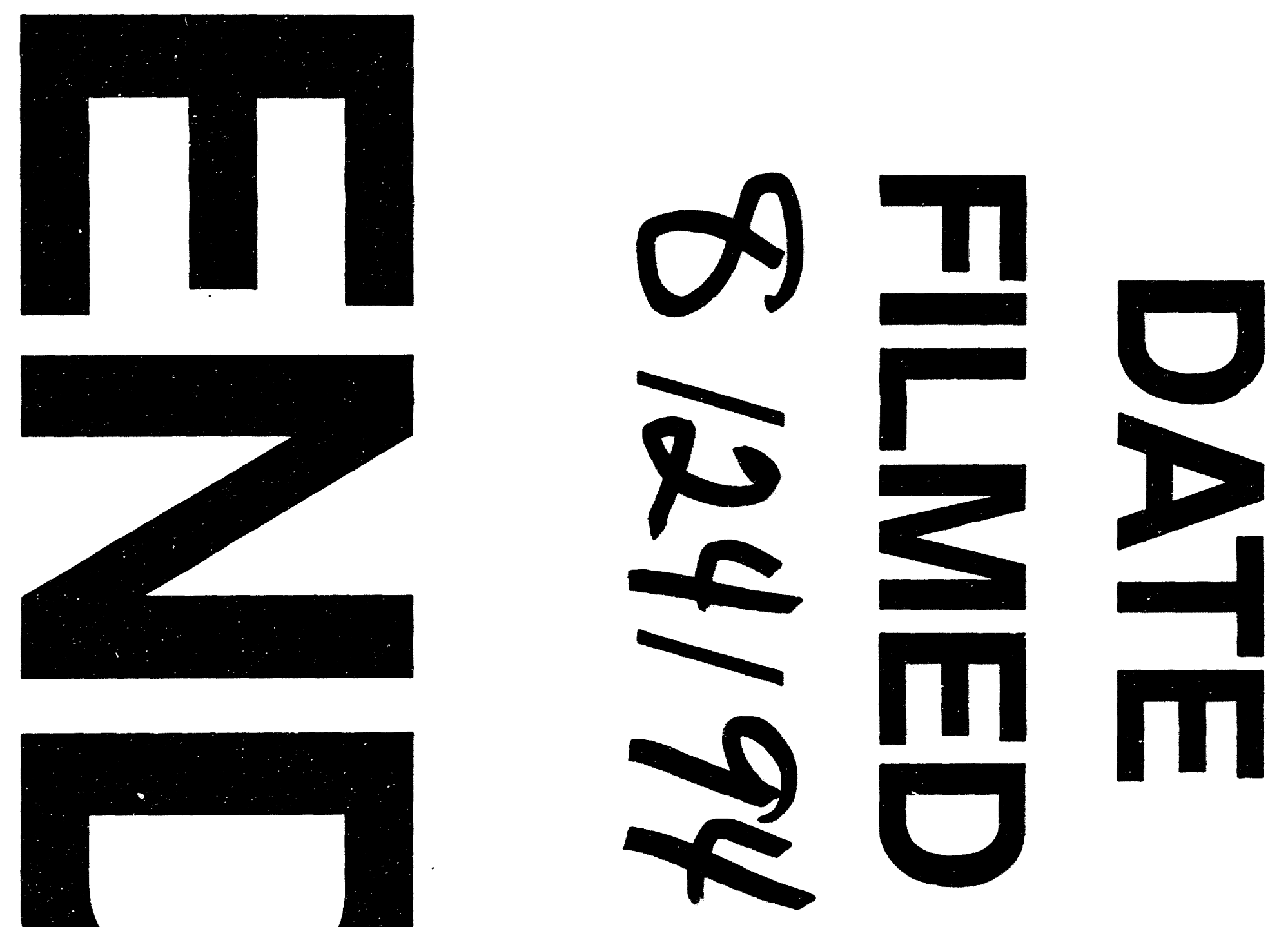